\title{
nam \\ Host Non-Coding RNA Regulates Influenza A Virus Replication
}

\author{
Yuejiao Liao ${ }^{1,2}$, Shouqing Guo ${ }^{1,2}$, Geng Liu ${ }^{1,2}$, Zhenyu Qiu ${ }^{1,2}$, Jiamin Wang ${ }^{1,3}$, Di Yang ${ }^{1,3}$, Xiaojing Tian ${ }^{2,3}(\mathbb{D}$, \\ Ziling Qiao ${ }^{1,3}$, Zhongren Ma ${ }^{1,3}$ and Zhenbin Liu ${ }^{1,3, *}$ \\ 1 Gansu Tech Innovation Center of Animal Cell, Biomedical Research Center, Northwest Minzu University, \\ Lanzhou 730030, China; lyj1997052@163.com (Y.L.); guoshouqing292196@163.com (S.G.); \\ lg13619271425@163.com (G.L.); Qiuzhenyu9810@163.com (Z.Q.); jiaminwang1987@163.com (J.W.); \\ xbmzyd@163.com (D.Y.); qiaozilin@xbmu.edu.cn (Z.Q.); mzr@xbmu.edu.cn (Z.M.) \\ 2 Life Science and Engineering College, Northwest Minzu University, Lanzhou 730030, China; \\ smile_tian@yeah.net \\ 3 Key Laboratory of Biotechnology \& Bioengineering of State Ethnic Affairs Commission, Biomedical \\ Research Center, Northwest Minzu University, Lanzhou 730030, China \\ * Correspondence: liuzhenbin6@163.com
}

check for updates

Citation: Liao, Y.; Guo, S.; Liu, G.; Qiu, Z.; Wang, J.; Yang, D.; Tian, X.; Qiao, Z.; Ma, Z.; Liu, Z. Host Non-Coding RNA Regulates Influenza A Virus Replication. Viruses 2022, 14, 51. https:// doi.org/10.3390/v14010051

Academic Editor: Craig McCormick

Received: 3 December 2021

Accepted: 21 December 2021

Published: 29 December 2021

Publisher's Note: MDPI stays neutral with regard to jurisdictional claims in published maps and institutional affiliations.

Copyright: (C) 2021 by the authors. Licensee MDPI, Basel, Switzerland. This article is an open access article distributed under the terms and conditions of the Creative Commons Attribution (CC BY) license (https:// creativecommons.org/licenses/by/ $4.0 /)$

\begin{abstract}
Outbreaks of influenza, caused by the influenza A virus (IAV), occur almost every year in various regions worldwide, seriously endangering human health. Studies have shown that host non-coding RNA is an important regulator of host-virus interactions in the process of IAV infection. In this paper, we comprehensively analyzed the research progress on host non-coding RNAs with regard to the regulation of IAV replication. According to the regulation mode of host non-coding RNAs, the signal pathways involved, and the specific target genes, we found that a large number of host non-coding RNAs directly targeted the PB1 and PB2 proteins of IAV. Nonstructural protein 1 and other key genes regulate the replication of IAV and indirectly participate in the regulation of the retinoic acid-induced gene I-like receptor signaling pathway, toll-like receptor signaling pathway, Janus kinase signal transducer and activator of transcription signaling pathway, and other major intracellular viral response signaling pathways to regulate the replication of IAV. Based on the above findings, we mapped the regulatory network of host non-coding RNAs in the innate immune response to the influenza virus. These findings will provide a more comprehensive understanding of the function and mechanism of host non-coding RNAs in the cellular anti-virus response as well as clues to the mechanism of cell-virus interactions and the discovery of antiviral drug targets.
\end{abstract}

Keywords: IAV; miRNA; lncRNA; circRNA; interferon; antiviral innate immune response

\section{Introduction}

Influenza viruses belong to the Orthomyxoviridae RNA virus family and is divided into genera A, B, C and D. Among them, genera A, B and C cause respiratory diseases in humans [1]. Influenza A virus (IAV) can infect a wide range of hosts and is highly infectious \& transmissible, and easily mutable, which can result in an influenza pandemic in a short time; therefore, it creates an enormous burden and pressure on the public health system [2,3]. The innate immune response is the first line of defense against virus infection and plays an important role in the process of resisting virus invasion [4]. In the process of IAV infection, the body relies on different pattern recognition receptors (PRRs) in cells to recognize virus-related molecular patterns, such as retinoic acid-induced gene I (RIG-I), melanoma differentiation factor 5 (MDA5), and toll-like receptors (TLRs). Many different molecular signals (such as: RIG-I, MDA5, TRAF3, IKK, TBK1) are also recruited to inhibit the replication of the influenza virus through a series of complex signal pathways, including PRR-dependent signal pathways, which can induce the production of interferon (IFN) and inflammatory factors, as well as the expression of antiviral IFN-stimulated genes 
(ISGs) [5-8]. These proteins not only inhibit the replication of viruses in infected cells but also recruit dendritic cells (DCs) and macrophages from virus-infected tissues and further stimulate the immune response mediated by T cells and B cells [9,10].

Non-coding RNAs (ncRNAs) are a large class of RNA transcripts that are transcribed from the genome but lack the ability to encode proteins [11]. At the RNA level, they can perform their respective biological functions and play an important role in cell growth, differentiation, replication, and apoptosis. Regulatory non-coding RNAs mainly include microRNA (miRNA), long non-coding RNA (lncRNA)and circular RNA (circRNA) [12,13]. MiRNA, lncRNA, and other non-coding RNA participate in gene expression regulation, thereby affecting cell replication and differentiation, individual growth and development, immune response, and other life activities [14-16]. Recent studies have shown that noncoding RNAs play an important role in regulating the interactions between host cells and viruses [17-19]. Influenza virus infection can induce significant changes in the expression of many hosts' non-coding RNAs, some of which are involved in regulating the antiviral response of host cells, while others promote the efficient replication of the virus [20,21]. In this paper, we systematically summarized the host non-coding RNAs that are involved in the regulation of influenza virus replication, performed summary analysis according to their inhibition or promotion of virus replication, and mapped the signal network of host non-coding RNAs that regulate the influenza virus response (see Figure 1 for relevant information).

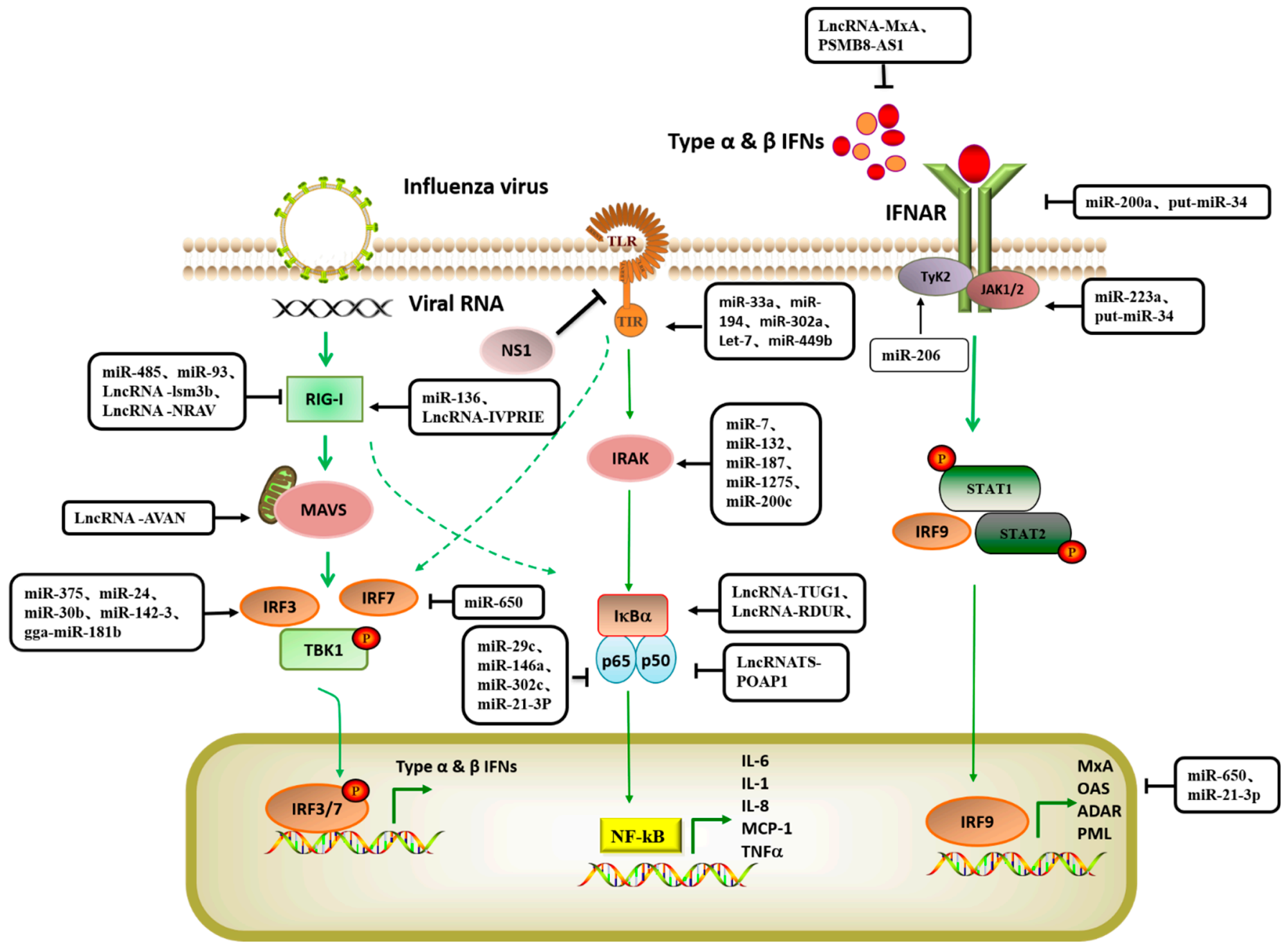

Figure 1. Host noncoding RNA involved in regulating influenza A virus response signal pathway. The natural immune response is the body's first line of defense against viral infection and involves 
the activation of multiple antiviral signal pathways as well as the activation and expression of antiviral factors. During this process, host noncoding RNAs are induced or inhibited by influenza virus infection, which mediates the activation of target genes, affects the expression of antiviral natural immune molecules, and indirectly regulates the replication and proliferation of influenza virus. The target gene sites in the natural immune response signaling pathway involved in the regulation of noncoding RNA are concentrated in the RLR signaling pathway, TLR-like receptor signaling pathway, JAK-STAT signal pathway, and NF-kB signaling pathway. (Dotted arrow is indirect effect; solid line is direct effect).

\section{Host miRNA Regulates IAV Replication}

MiRNAs are widely distributed in eukaryotes and some viral genomes. They are highly conserved non-coding single-stranded RNA fragments encoded by nuclear genes and play a role in the regulation of post-transcriptional gene expression [22,23]. In animal cells, miRNA mediates the inhibition of target gene expression or mRNA degradation by recognizing the $5^{\prime}$-UTR-3'-UTR of target gene mRNA to form a 2-8nt complementary structure and also regulates the expression of key genes in different signaling pathways [24,25]. Analyzing the miRNA reported to be involved in the regulation of IAV revealed that the host miRNA regulation of viral gene expression can be divided into two parts. First, the miRNA directly targets the mRNAs of the influenza virus, inhibits the expression of viral proteins, or mediates the degradation of viral mRNAs, thereby inhibiting the replication of the virus. Second, the miRNA indirectly regulates the replication of the influenza virus by targeting key genes in the influenza virus response signaling pathway.

\subsection{Host miRNA Directly Inhibits IAV Gene Expression}

From the perspective of IAV infection, cell miRNA expression is crucial for virus-host interactions such as virus entry, replication, translation, and transmission. When H9N2 or H5N1 infected avian-derived DCs, gga-miR6675 and gga-miR6616 were found to target of mRNA nuclear localization sequence (NLS) of viral PB1, triggering PB1 gene silencing and inhibiting H9N2 replication. (See Table 1 for relevant information) The study may provide new insights into the interactions between bird miRNA and bird DCs and the inhibition of virus replication [26]. In A549 cells with high expression of miR-3145, miR-3145 can silence the $3^{\prime}$-UTR of the PB1 gene for the H5N1, H1N1, and H3N2 subtypes of IAV, reduce gene expression and inhibit virus replication [27]. In addition, miR-323, miR-491, and miR-654 contain the same nucleotide sequence, which can down-regulate the expression of the PB1 gene through the conserved region of the PB1 gene for the H1N1 virus, thereby inhibiting the replication of the virus in Madin-Darby canine kidney cells [28]. In A549 cells, miR-188-3p inhibited the gene expression of PB2 by binding to its mRNA and effectively inhibited the replication of IAV (H1N1, H5N6, and H7N9) [29]. Host non-coding RNAs, such as miR-584-5p [30] and miR-485 [31] have been reported to act on the PA, PB1, and PB2 genes of IAV, inhibiting mRNA expression thereby reducing virus replication.

In addition to regulating the expression of the PA, PB1, and PB2 genes of IAV, host miRNA can also inhibit the replication of IAV by binding to different target gene sites of the influenza virus, thus reducing the risk of influenza virus escape. NS1 protein of influenza A virus has been shown to induce cell cycle stagnation in the G0/G1 phase, providing a more favorable cell environment for virus replication [32]. It has been reported that hsa-miR-1307-3p is a novel and effective inhibitor of NS1 expression and influenza virus replication. Type I IFN induces the up-regulation of hsa-miR-1307-3p expression during H1N1 infection of A549 cells, and hsa-miR-1307-3p directly targets the viral gene NS1. Inhibition of NS1 gene expression, can reduce the impact of virus infection on the cell cycle, and ultimately inhibit the replication of IAV [33]. Studies have shown that not only does influenza virus infection induce some miRNAs in the host to exert antiviral effects but non-host encoded miRNAs also have anti-influenza effects. miR-2911 is an atypical miRNA encoded by Honeysuckle and can negatively regulate PB2 and NS1 protein gene expression by a variety of avian influenza viruses. In mouse model tests, miR-2911 
inhibited the replication of H1N1, H5N1, and H7N9 viruses in mice, prevented weight loss and death caused by an influenza virus infection and was found to be a potential and effective broad-spectrum antiviral factor against viral infection [34]. The replication and transcription of IAV depend on nucleoprotein (NP) genes [35]. The $5^{\prime}$ seed regions of cfa-miR-125b and cfa-miR-151 are partially complementary to the mRNA of NP and NS1 of the avian influenza H3N2 virus [36]. MiR-769-3p targets the expression of influenza virus NP protein [29], while let-7c significantly inhibits the replication of influenza virus in A549 cells by binding to the $3^{\prime}$-UTR region of the M gene of IAV [37]. SSC-miR-221-3p acts as a host barrier to regulate nuclear factor kappa B (NF-kB) P65 phosphorylation, inhibit the expression of anti-apoptotic protein $\mathrm{HMBOX} 1$, and induce apoptosis during the cross-species infection of IAV, or by targeting and silencing the hemagglutinin (HA) gene of the H5 subtype, restricting the infection and replication of influenza viruses [38].

Table 1. miRNA directly targets key genes of viruses.

\begin{tabular}{|c|c|c|c|c|c|c|}
\hline miRNA & Target $^{\text {a }}$ & Cell Type & Virus & $\begin{array}{c}\text { Induced } \\
\text { Expression }\end{array}$ & $\begin{array}{l}\text { Binding Site of } \\
\text { Target }{ }^{c}\end{array}$ & References \\
\hline $\begin{array}{l}\text { miR-323 } \\
\text { miR-491 } \\
\text { miR-654 }\end{array}$ & \multirow{6}{*}{ PB1 } & MDCK & $\begin{array}{c}\text { H1N1 } \\
\text { (A/WSN/33) }\end{array}$ & UP & CCACC & [28] \\
\hline miR-3145 & & A549 & $\begin{array}{c}\text { H5N1 } \\
\text { (A/Thailand/NK165/2005) } \\
\text { H1N1 } \\
\text { (A/Thailand/104/2009) } \\
\text { H3N2 } \\
\text { (A/Thailand/ } \\
\text { CU-H1817/2010) }\end{array}$ & UP & $\begin{array}{l}\text { UAUGGAGCUGCCC } \\
\text { GCUUUGGAGUGUC } \\
\text { UUUGGAGUGUCU }\end{array}$ & [27] \\
\hline miR-485 & & HEK293T & $\begin{array}{c}\text { H5N1 } \\
\text { (A/duck/India/02CA10/2011) }\end{array}$ & UP & CAGCCUC & [31] \\
\hline miR-324-5p & & A549 & $\begin{array}{c}\text { H5N1 } \\
\text { (A/duck/India/02CA10/2011) }\end{array}$ & DOWN & GAGGGGAT & [39] \\
\hline gga-miR6675 & & HEK293T & $\begin{array}{c}\text { H9N2 } \\
\text { (A/NJO2/2009) }\end{array}$ & UP & - & [26] \\
\hline $\operatorname{miR}-4753$ & & A549 & $\begin{array}{c}\text { H5N1 } \\
\text { (A/Thailand/NK165/2005) }\end{array}$ & UP & AGAGAAAGAGAA & [27] \\
\hline $\begin{array}{c}\text { miR-584-5p } \\
\text { miR-1249 }\end{array}$ & \multirow[b]{2}{*}{ PB2 } & A549 & $\begin{array}{c}\text { H1N1 } \\
\text { (A/Beijing/501/2009) } \\
\text { H5N1 } \\
\text { (A/goose/Jilin/hb/2003) }\end{array}$ & DOWN & $\begin{array}{l}\text { GCAAACCA } \\
\text { GGAGGGC }\end{array}$ & [30] \\
\hline miR-188-3p & & A549 & $\begin{array}{c}\text { H1N1(A/FM/1/47) } \\
\text { H5N6 } \\
\text { (A/chicken/Hubei/XY918/2016) } \\
\text { H7N9 } \\
\text { (A/quail/Hebei/CH06- } \\
\text { 07/2018) }\end{array}$ & UP & $\begin{array}{l}\text { TGTGGGA } \\
\text { ATGTGGGA } \\
\text { ATGTGGGA }\end{array}$ & [29] \\
\hline hsa-miR-1307-3p & \multirow{3}{*}{ NS1 } & A549 & $\begin{array}{c}\text { H1N1 } \\
\text { (A/California/04/2009) }\end{array}$ & UP & CGCCGAG & [33] \\
\hline miR-3682 & & A549 & $\begin{array}{c}\text { H1N1 } \\
\text { (A/Thailand/104/2009) } \\
\text { H3N2 } \\
\text { (A/Thailand/ } \\
\text { CU-H1817/2010) }\end{array}$ & UP & $\begin{array}{l}\text { GUAUCGUC } \\
\text { AUGAUAACACAG }\end{array}$ & [27] \\
\hline miR-4331 & & NPTR & H1N1 & DOWN & $\begin{array}{c}\text { TGGCCT } \\
\text { ACAGCCAC }\end{array}$ & [40] \\
\hline
\end{tabular}


Table 1. Cont.

\begin{tabular}{|c|c|c|c|c|c|c|}
\hline miRNA & Target $^{a}$ & Cell Type & Virus & $\begin{array}{c}\text { Induced } \\
\text { Expression } b\end{array}$ & $\begin{array}{l}\text { Binding Site of } \\
\text { Target }\end{array}$ & References \\
\hline miR-584-5P & \multirow{2}{*}{ M1 } & A549 & $\begin{array}{c}\text { H5N1 } \\
\text { (A/goose/Jilin/hb/2003) }\end{array}$ & UP & GCAAACCA & {$[30]$} \\
\hline let-7c & & A549 & $\begin{array}{c}\text { H1N1 } \\
\text { (Jing Fang/86-1) }\end{array}$ & UP & АСТАССТ & [37] \\
\hline miR-204 & \multirow{3}{*}{ HA } & NPTR & $\begin{array}{c}\text { H1N1 } \\
\text { (A/swine/Nanchang/F9/2010) }\end{array}$ & DOWN & AAAGGGA & [40] \\
\hline miR-192 & & A549 & $\begin{array}{l}\text { H5N1 } \\
(\mathrm{A} / \mathrm{PR} 8)\end{array}$ & UP & $-^{d}$ & [41] \\
\hline ssc-miR-221-3p & & PAM & $\begin{array}{c}\text { H5N1 } \\
\text { (A/duck/An-hui/1/2006) }\end{array}$ & DOWN & AAUGUGGUA & [38] \\
\hline miR-1249 & \multirow[b]{2}{*}{ NA } & A549 & $\begin{array}{c}\text { H5N1 } \\
\text { (A/goose/Jilin/hb/2003) } \\
\text { H1N1 } \\
\text { (A/Beijing/501/2009) }\end{array}$ & UP & GGAGGGC & [30] \\
\hline $\operatorname{miR}-216 b$ & & A549 & $\begin{array}{c}\text { H5N1 } \\
\text { (A/Thailand/NK165/2005) } \\
\text { H3N2 } \\
\text { (A/Thailand/ } \\
\text { CU-H1817/2010) }\end{array}$ & UP & $\begin{array}{l}\text { UGCAGGGAU } \\
\text { UGUCUGCAGAGA }\end{array}$ & [27] \\
\hline $\operatorname{miR}-4513$ & \multirow{3}{*}{ PA } & A549 & $\begin{array}{c}\text { H1N1 } \\
\text { (A/Thailand/104/2009) } \\
\text { H3N2 } \\
\text { (A/Thailand/ } \\
\text { CU-H1817/2010) }\end{array}$ & UP & UCGUCAGUC & [27] \\
\hline miR-5693 & & A549 & $\begin{array}{c}\text { H5N1 } \\
\text { (A/Thailand/NK165 } \\
\text { /2005) } \\
\text { H3N2 } \\
\text { (A/Thailand } \\
\text { /CU-H1817/2010) }\end{array}$ & UP & $\begin{array}{l}\text { UAGAGCCACUG } \\
\text { AGAGAAAGAGAA }\end{array}$ & [27] \\
\hline ssc-miR-222 & & HEK293T & $\begin{array}{c}\text { H5N1 } \\
\text { (A/duck/An-hui/1/2006) }\end{array}$ & UP & GAUGUGGUA & [38] \\
\hline
\end{tabular}

${ }^{a}$ : miRNA directly target key genes of viruses; ${ }^{b}$ : induced expression of miRNA after influenza virus infection; c: sequences of miRNA binding site of target $\left(5^{\prime}-3^{\prime}\right),{ }^{\mathrm{d}}$ : ' - ' means unknown.

\subsection{Host miRNAs Indirectly Inhibit IAV Replication by Regulating Intracellular Signaling}

In the process of IAV infection, the body relies on different PRRs in the cell to recognize the molecular patterns associated with the virus, activate the expression of IFNs, activate the downstream signaling pathway, release a large number of inflammatory factors such as interleukins (ILs), and initiate the antiviral immune response. Studies have shown that host miRNAs can be involved in regulating the activation of host PRR-mediated antiviral signaling pathways, thereby indirectly inhibiting the replication of influenza viruses. (See Table 2 for relevant information).

Host miRNA inhibits IAV replication by regulating TLR-mediated innate immune response signaling pathways. In THP-1 cells infected with H7N9, let-7e enhanced the immune response of host cells, reduced the expression of HA, and inhibited the replication of the virus by participating in the inflammatory response mediated by the TLR4 of host cells. It also regulated the inflammatory response and mediated the anti-inflammatory process by targeting IL-1 and IL-6, preventing an excessive inflammatory response [42]. In addition, host miRNA such as miR-200a [43], miR-29c [44], miR-650 [45], miR-206 [46], and hsa-miR-664a-3p [47] have been reported to induce IFN expression by mediating TLR signaling pathways during the process of IAV infection, inhibiting the replication and proliferation of IAV. According to studies, miRNA-155 participates in the regulation of a variety of biological processes and also plays an important regulatory role in the infection of influenza virus and other viruses, mainly affecting the JAKs-STATs and TLRs/NF- $\mathrm{kB}$ sig- 
naling pathway to regulate viral replication and the antiviral response of the body [48-50]. For example, human lung microvascular endothelial cells are infected with H1N1 influenza virus, miR-155 is induced by H1N1 infection. Overexpression of miR-155 enhances the expression of inflammatory factors and activation of NF- $\mathrm{KB}$ factor. Sphingosine-1-phosphate receptor 1 (S1PR1) is a target of miR-155. S1PR1 is widely expressed in endothelial cells, immune cells, lymphocytes, macrophages, muscle, and other tissue cells. Mir-155 actively regulates influenza A-induced inflammation by targeting S1PR1 [51]. Another new study showed that miRNA-155-5P was effective in alleviating acute respiratory distress syndrome (ARDS) caused by influenza virus infection [52]. In addition, evidence shows that miR155 also plays a role in the adaptive immune response induced by the influenza virus, controlling $\mathrm{CD} 8+\mathrm{T}$ cell response by regulating interferon signaling. The miR-155-KO dendritic cells cannot effectively present antigen and miR-155 in CD8+ T cells can control the differentiation of Th1, Th2, and Th17 subsets and affect the development of TREG cells [53].

Host miRNA inhibits IAV replication by regulating RIG-I-like receptor (RLR)-mediated innate immune response signaling pathways. RLRs play a critical role in host innate immunity, and mice with either RIG-I or MDA5 deficiency have shown susceptibility to RNA viruses [54]. When an IAV infects a host cell, viral RNA is recognized by RIG-I and MDA5, respectively, activating the signaling pathways of the innate immune response. Overexpressed RIG-I and MDA5 strongly activate the IFN- $\beta$ promoter and up-regulate the expression of antiviral molecules such as $2^{\prime}-5^{\prime}$ oligoadenylate synthetase (OAS), doublestranded RNA-dependent protein kinase (PKR) and myxovirus resistance protein A (MxA) and inflammatory factors (such as IL-2, IL-6, IFN- $\alpha$, and IFN- $\gamma$ ) [55]. MiR-136 was identified as a novel endogenous RIG-I activator that may contribute to the control of influenza virus disease. The expression of miR136 was upregulated five-fold following H5N1 influenza virus infection in A549 cells. In vitro experiments showed that miR136 exhibited strong antiviral activity against both the H5N1 influenza virus and Indiana Vesicular Stomatitis Virus (VSV). Further UTR reporter gene analysis revealed that the $3^{\prime}$-UTR of IL-6 is the target of miR-136, which also acts as an immune agonist for RIG-I, causing the accumulation of IL- 6 and IFN- $\beta$ in A549 cells. These results indicate that miR136 has dual functions of mediating post-transcriptional regulation and immune activation, enhancing the antiviral effect by promoting the expression of antiviral and inflammatory factors [56].

Host miRNA induces interferon expression by regulating the Janus kinase signal transducer and activator of transcription (JAK-STAT) signaling pathway and inhibits the replication and proliferation of IAV. The antiviral effect of IFN mainly occurs through the activation of the JAK/STAT signal, which induces the production of ISGs. IFN regulatory factor 5 (IRF-5) is a key transcription factor for maintaining the inflammatory phenotype of macrophages. IRF- 5 can promote the replication of IAV, while miR-302a regulates the cytokine storm induced by IAV by binding to the $3^{\prime}$-UTR of IRF- 5 and interferes with the replication of influenza virus $[57,58]$. IAVs inhibit the host type I IFN-mediated antiviral immune response by reducing the expression of miR-30, which targets and reduces the expression of suppressor of cytokine signaling 1 (SOCS1) and suppressor of cytokine signaling 3 (SOCS3), thereby reducing their inhibitory effects on the IFN/JAK/STAT signaling pathway. In addition, miR-30 inhibits the expression of the interferon-induced transmembrane proteins 3 (IFITM3) negative regulator neuronal precursor cell-expressed developmentally downregulated 4 (NEDD4) [59]. A recent study found that overexpression of miR-206 in A549 cells significantly inhibited mRNA expression of NP, NS1, and PB1 by the H1N1 and H3N2 influenza viruses, decreased the protein expression of NP and NS1, and significantly reduced influenza virus titers. The $3^{\prime}$-UTR reporter gene assay showed that miR-206 binding to the $3^{\prime}$-UTR of tankyrases2 (TNKS2) activated JNK/c-Jun signaling, induced type I IFN expression, enhanced STAT signaling, reduced the viral load in the lungs, and improved the survival rate of mice [46].

Host miRNA inhibits IAV replication through other antiviral pathways. The antigen presentation ability of DCs plays an irreplaceable role in the recognition and removal of viruses. Host miRNA can inhibit the replication of IAV by regulating the antigen 
presentation of host DCs. Both active and inactive H9N2 avian influenza viruses can enhance the ability of DCs to present antigens and activate T lymphocytes. GGA-miR1644 enhances the ability of DCs to inhibit viral replication by muscle blind-like protein 2 . This study provides new clues for the role of miRNAs in inducing DC antigen presentation and inhibiting virus replication [26].

Host miRNA can inhibit the replication of IAV by regulating cell apoptosis. In the process of cross-species infection by the influenza virus, ssc-miR-221-3p and ssc-miR-222 can induce the apoptosis of positive allosteric modulators (PAM) cells by directly targeting the mRNA of HA and PA genes and the expression of the anti-apoptotic protein HMBOX1. Moreover, these two miRNAs inhibited the infection and replication of IAV in newborn pig trachea (NPTR) cells. Compared to Simian immunodeficiency virus (SIV) infection, P65 can be phosphorylated more efficiently after IAV infection, which is why the expression of ssc-miR-221-3p and ssc-miR-222 is significantly upregulated after viral infection [38]. According to a previous study, the stromal interaction molecule 1 (STIM1)/miR-223/nodlike receptor pyrins-3 (NLRP3) axis can regulate the inflammatory damage of lung epithelial cells induced by IAV. By inhibiting the activation of the TLR4/NF- $\mathrm{kB}$ signaling pathway and NLRP3 inflammasome, miR-223 alleviated the oxidative stress and apoptosis of lung epithelial cells induced by IAV and alleviated cell damage. In the serum of patients infected with IAV, STIM1 was significantly upregulated, while miR-223 was down-regulated. STIM1 regulates the expression of NLRP3 by binding to the AACUGAC sequence in miR-223. In vitro silencing of STIM1 can promote the expression of miR-223 and inactivate NLRP3 and inflammasome, inhibit the oxidative stress and inflammatory response induced by IAV, reverse cell viability, inhibit cell apoptosis, and thereby reduce the inflammatory damage of lung epithelial cells induced by IAV [60]. MiR-29a binds to the $3^{\prime}$-UTR binding site of the Wnt/Ca signal receptor frizzled5 gene, reduces the expression level of endogenous frizzled5 protein, reduces the mRNA and protein levels of IAV, and also reduces the production of the progeny virus. Moreover, the inhibitory effect of miR-29a on IAV infection was observed in A/PR/8/34, A/WSN/1933, A/OK/3052/09, and A/OK/309/06 H3N2 and other influenza virus strains [61].

\subsection{Host miRNAs Promote the Replication of IAV}

During the interactions between the influenza virus and host, host miRNAs inhibit virus replication directly and indirectly. However, some studies have shown that the miRNAs can negatively regulate the antiviral response pathway, reduce the expression of antiviral factors, and promote the replication of the influenza virus.

Host miRNAs negatively regulate TLR and RLR-mediated innate immune response pathways to promote IAV replication. The expression of miR-21-3p was significantly reduced in A549 cells infected with $\mathrm{H} 5 \mathrm{N1}$, and miR-21-3p down-regulated the expression of basic fibroblast growth factors 2 (FGF2) recombinant proteins, accelerated the replication of $\mathrm{H} 5 \mathrm{~N} 1$, and inhibited the IFN response. The overexpression of miR-21-3p significantly increased the expression levels of viral genes M1 and NP and viral titers in influenza virus-infected cells and significantly decreased the expression of antiviral factors such as IFN, PKR, MxA, and OAS [62]. In addition, miR-21-3p can promote the replication of IAV by inhibiting the expression of the histone deacetylase-8 (HDAC8)-inhibiting gene by targeting the $3^{\prime}$-UTR gene of HDAC8 [63]. Type I IFN plays an important role in host resistance to influenza virus infection. In type II alveolar epithelial cells infected with IAV, host miR-93 was inhibited in the RIG-I/JNK pathway, and the target protein gene JAK1 of miR-93 was up-regulated. This promoted IFN signal transduction and thus improved antiviral ability. In vivo injection of miR-93 antagonist significantly inhibited IAV infection and protected mice from IAV-related death [64].

Host miRNA negatively regulates NF- $\kappa B$ and IRF-mediated innate immune response signaling pathways to promote IAV replication. As a pro-inflammatory cytokine, zinc finger protein A20 participates in the negative feedback regulation of IL-I/tumor necrosis factor and other types of signal transduction and plays a role in inhibiting the antiviral 
immune response in the NF- $\mathrm{kB}$ and IRF signaling pathways. Influenza virus infection induces the up-regulation of miR-29c expression and stabilizes the expression of A20, thus improving the capacity for viral replication [44]. In IAV-infected monocyte-derived DCs, the regulation level of miR650 was negatively correlated with the mature state of DCs. In IAV-infected monocyte-derived dendritic cells, influenza viruses utilize the host miR-650 to target the $3^{\prime}$-UTR of antiviral factor MxA to reduce the expression of antiviral protein and to improve viral replication [45]. IAV is one of the most common pathogens that cause ARDS. Infected epithelial cells release a large number of inflammatory mediators, mediating endothelial leakage, and neutrophils are recruited into the lung, resulting in decreased epithelial-endothelial barrier function, aggravating alveolar edema, and leading to respiratory failure [65].

These results indicate that some host miRNAs can directly regulate viral gene expression during host-influenza virus interaction. In addition, some host miR-RNAs indirectly regulate the replication of the influenza virus by regulating the antiviral immune response signal in host cells. These findings provide new ideas for a comprehensive understanding of the interaction mechanism between host cells and influenza virus and the discovery of effective targets for antiviral drugs.

Table 2. Host miRNAs indirectly regulate influenza A virus replication.

\begin{tabular}{|c|c|c|c|c|c|c|c|}
\hline $\begin{array}{l}\text { Signaling } \\
\text { Pathways }\end{array}$ & Target Gene ${ }^{b}$ & miRNA & Cell Type & $\begin{array}{l}\text { Regulation } \\
\text { Direction }^{c}\end{array}$ & Virus & $\begin{array}{c}\text { Induced } \\
\text { Expression }\end{array}$ & References \\
\hline \multirow{3}{*}{ RLRS } & RIG-1 & $\operatorname{miR}-485$ & HEK293T & Promote & $\begin{array}{c}\text { H5N1 } \\
\text { (A/duck/India/02CA10/2011) }\end{array}$ & UP & [31] \\
\hline & RIG-1, IL-6 & miR-136 & A549 & Inhibition & $\begin{array}{c}\text { H5N1 } \\
\text { (A/duck } \\
\text { /Hubei } \\
\text { /hangmei01/2006) }\end{array}$ & UP & [56] \\
\hline & RIG-1 & $\operatorname{miR}-93$ & A549 & Promote & $\begin{array}{c}\text { H1N1 } \\
(\mathrm{A} / \\
\text { Puerto Ri-co/8/1934) }\end{array}$ & DOWN & [64] \\
\hline \multirow{6}{*}{ TLRS } & ARCN1 & $\operatorname{miR}-33 a$ & A549, Hela & Inhibition & $\begin{array}{c}\text { H1N1 } \\
(\mathrm{A} / \mathrm{WSN} / 33) \\
\text { H9N2 } \\
\text { (A/Chicken/Liaoning/1/100) }\end{array}$ & UP & [66] \\
\hline & FGF2 & miR-194 & A549 & Inhibition & $\begin{array}{c}\text { H1N1 } \\
\text { (IAV / } \\
\text { Beijing/501/2009) }\end{array}$ & UP & [67] \\
\hline & IRF5 & miR-302a & A549 & Inhibition & $\begin{array}{c}\text { H1N1 } \\
(\mathrm{A} / \mathrm{FM} / 1 / 47)\end{array}$ & DOWN & [59] \\
\hline & $\begin{array}{l}\text { IRAK1, } \\
\text { MAPK3 }\end{array}$ & $\begin{array}{l}\text { miR-7, } \\
\text { miR-132, } \\
\text { miR-187, } \\
\text { miR-1275, } \\
\text { miR-200c }\end{array}$ & A549 & Inhibition & $\begin{array}{c}\text { H1N1 } \\
(\mathrm{A} / \mathrm{WSN} / 33)\end{array}$ & UP & [68] \\
\hline & HDAC1 & $\mathrm{miR}-449 \mathrm{~b}$ & A549 & Inhibition & $\begin{array}{c}\mathrm{H} 1 \mathrm{~N} 1 \\
(\mathrm{~A} / \mathrm{WSN} / 33)\end{array}$ & UP & [69] \\
\hline & TOLL 4 & Let-7e & THP-1 & Inhibition & $\begin{array}{c}\text { H7N9 } \\
\text { (A/Anhui/1/2013) }\end{array}$ & UP & [42] \\
\hline \multirow[t]{2}{*}{ NF- $k B$} & $\begin{array}{l}\text { IRAK-1, } \\
\text { TRAF6 }\end{array}$ & miR-146a & Hela & Inhibition & $\begin{array}{c}\text { H1N1 } \\
\text { (A/Jing fang/01/1986) } \\
\text { H3N2 } \\
(\mathrm{A} / \mathrm{Lu} \mathrm{fang} / 09 / \\
1993)\end{array}$ & UP & [70] \\
\hline & TRAF6 & miR-144 & HBE & Inhibition & $\begin{array}{c}\text { H1N1 } \\
\text { (A/ } \\
\text { Puerto Ri-co/8/34) }\end{array}$ & UP & [71] \\
\hline
\end{tabular}


Table 2. Cont.

\begin{tabular}{|c|c|c|c|c|c|c|c|}
\hline $\begin{array}{l}\text { Signaling } \\
\text { Pathways }\end{array}$ & Target Gene $^{b}$ & miRNA & Cell Type & $\begin{array}{l}\text { Regulation } \\
\text { Direction }^{c}\end{array}$ & Virus & $\begin{array}{l}\text { Induced } \\
\text { Expression }\end{array}$ & References \\
\hline & NFKBIB & miR-4776 & MDCK & Inhibition & $\begin{array}{c}\text { H1N1 } \\
(\mathrm{A} / \mathrm{WSN} / 33)\end{array}$ & UP & [72] \\
\hline & BCL2L2 & $\operatorname{miR}-29 c$ & A549 & Inhibition & $\begin{array}{c}\text { H1N1 } \\
(\mathrm{A} / \text { Jing fang/01/1986) }\end{array}$ & UP & [44] \\
\hline & NIK & miR-302c & A549 & Promote & $\begin{array}{c}\text { H3N2 } \\
\text { (A/Hong Kong/498/97) }\end{array}$ & DOWN & [57] \\
\hline & TRAF6 & miR-146a & A549 & Promote & $\begin{array}{c}\text { H1N1 } \\
\text { (A/Jing fang/01/ } \\
\text { 1986) } \\
\text { H3N2 } \\
\text { (A/Lu fang/09/1993) }\end{array}$ & UP & [70] \\
\hline & A20 & miR-29c & A549 & Promote & $\begin{array}{c}\text { H1N1 } \\
\text { (A/Jingfang/01/1986) }\end{array}$ & UP & {$[44]$} \\
\hline & HDACB & miR-21-3P & A549 & Promote & $\begin{array}{c}\text { H5N1 } \\
\text { (A/goose/Ji-Lin/ } \\
\text { hb/2003) } \\
\text { H1N1 } \\
\text { (A/Beijing/501/2009) }\end{array}$ & DOWN & [63] \\
\hline & FGF2 & & & Promote & $\begin{array}{c}\text { H5N1 } \\
\text { (A/Hong Kong/156/97) }\end{array}$ & DOWN & [62] \\
\hline & IRF3, IRF7 & $\begin{array}{l}\text { miR-24, } \\
\text { gga-miR- } \\
\text { 30b, } \\
\text { miR-142-3 }\end{array}$ & A549 & Inhibition & $\begin{array}{c}\text { H9N2 } \\
\text { (environment/HN/1-18/2007) }\end{array}$ & UP & [73] \\
\hline & & $\begin{array}{l}\text { miR-375, } \\
\text { gga-miR- } \\
181 b\end{array}$ & Chicken & Inhibition & $\begin{array}{c}\text { H9N2 } \\
\text { (environment/HN/1-18/2007) }\end{array}$ & UP & \\
\hline & USP3 & miR-26a & MDCK & Inhibition & $\begin{array}{c}\text { H1N1 } \\
(\mathrm{A} / \mathrm{WSN} / 33)\end{array}$ & UP & [74] \\
\hline \multirow{6}{*}{ Jak-STAT } & STIM1 & $\operatorname{miR}-223 a$ & A549 & Inhibition & $\begin{array}{c}\text { H1N1 } \\
\text { (A/Puerto Rico/8/34) }\end{array}$ & UP & [60] \\
\hline & $\begin{array}{l}\text { IFNAR1, } \\
\text { STAT2 }\end{array}$ & miR-200a & A549 & Promote & $\begin{array}{c}\text { H1N1 } \\
\text { (r1918 and A/Texas/36/91) }\end{array}$ & DOWN & [43] \\
\hline & CUEDC2 & $\begin{array}{l}\text { miR-324- } \\
\quad 5 p\end{array}$ & A549 & Inhibition & $\begin{array}{c}\text { H5N1 } \\
\text { (A/duck/India/02CA10/2011) }\end{array}$ & DOWN & [39] \\
\hline & $\begin{array}{l}\text { IRF3, IFIT2, } \\
\text { MxA }\end{array}$ & miR-650 & NK & Promote & $\begin{array}{c}\text { H1N1 } \\
\text { (A/Puerto Rico/8/34) }\end{array}$ & DOWN & [45] \\
\hline & JNK/c-Jun & miR-206 & A549 & Inhibition & $\begin{array}{c}\text { H1N1 } \\
\text { (A/ } \\
\text { Puerto Rico/8/34) } \\
\text { H3N2 } \\
\text { (A/Oklahoma/309/2006) }\end{array}$ & DOWN & [46] \\
\hline & STAT3 & $\begin{array}{l}\text { put-miR- } \\
34\end{array}$ & HBE & Inhibition & $\begin{array}{l}\text { H9N1 } \\
(1 \mathrm{WF} 10)\end{array}$ & DOWN & [75] \\
\hline \multirow{3}{*}{ Apoptosis } & C0X6C & miR-4276 & A549 & Inhibition & $\begin{array}{c}\text { H1N1 } \\
(\mathrm{A} / \mathrm{WS} / 33) \\
\text { H3N2 } \\
(\mathrm{A} / \text { Aichi/2/68) }\end{array}$ & UP & [76] \\
\hline & HMBOX1 & $\begin{array}{l}\text { ssc-miR- } \\
221-3 p \\
\text { ssc-miR- } \\
222\end{array}$ & PAM & Inhibition & $\begin{array}{c}\text { H5N1 } \\
\text { (A/duck/Anhui/1/2006) }\end{array}$ & UP & [38] \\
\hline & MCPIP1 & miR-9 & A549 & Promote & $\begin{array}{c}\text { H1N1 } \\
(\mathrm{A} / \mathrm{PR} / 8 / 34) \\
\text { H3N2 } \\
\text { (A/Lufang/9/93) }\end{array}$ & UP & [77] \\
\hline
\end{tabular}


Table 2. Cont.

\begin{tabular}{|c|c|c|c|c|c|c|c|}
\hline $\begin{array}{l}\text { Signaling } \\
\text { Pathways a }\end{array}$ & Target Gene $^{\mathbf{b}}$ & miRNA & Cell Type & $\begin{array}{l}\text { Regulation } \\
\text { Direction }^{c}\end{array}$ & Virus & $\begin{array}{l}\text { Induced } \\
\text { Expression }\end{array}$ & References \\
\hline & IL-6 & $\begin{array}{l}\text { miR-let-7b- } \\
\text { MRE }\end{array}$ & $\mathrm{HBE}$ & Inhibition & $\begin{array}{c}\text { H1N1 } \\
\text { (A/Nanjing/NJU-108/2009) }\end{array}$ & UP & [78] \\
\hline MAPK/ERK & Vimentin & $\operatorname{miR}-1290$ & A549 & Promote & $\begin{array}{c}\text { H1N1 } \\
\text { (A/Taiwan/126/2009) }\end{array}$ & UP & [79] \\
\hline Muscleblind & Mbnl3 & miR-674 & Dendritic & Inhibition & $\begin{array}{c}\text { H9N2 } \\
\text { (A/duck/ } \\
\text { Nanjing } \\
\text { /01/1999) }\end{array}$ & UP & [80] \\
\hline $\begin{array}{l}\text { Wnt } / \beta- \\
\text { catenin }\end{array}$ & frizzled 5 gene & miR-29a & $\begin{array}{l}\text { HEK293T } \\
\text { A549 }\end{array}$ & Inhibition & $\begin{array}{c}\text { H3N2 } \\
\text { (A/Oklahoma//309/2006) }\end{array}$ & UP & {$[61]$} \\
\hline DC/TCell & DR1 & miR-203 & A549 & Inhibition & $\begin{array}{c}\text { H5N1 } \\
\text { (A/Vietnam/1194/2004 }\end{array}$ & UP & [81] \\
\hline mTOR & mTOR & miR-101 & A549 & Inhibition & $\begin{array}{c}\text { H5N1 } \\
\text { (A/Hatay/2004) }\end{array}$ & UP & [82] \\
\hline
\end{tabular}

a: Signaling pathways involved in regulation by miRNAs; ${ }^{b}$ : target genes bound by miRNAs in the signaling pathway; ${ }^{\text {c: }}$ miRNA mediated regulation of influenza virus replication; ${ }^{d}$ : induced expression of miRNA after influenza virus infection.

\section{Host LncRNAs Regulates IAV Replication}

According to reports, lncRNA, as a new type of regulatory factor, can be induced by the influenza virus and expressed in the cytoplasm or nucleus [83,84]. These lncRNAs can interact with a variety of biological macromolecules, directly or indirectly playing an important role in the host antiviral pathway or influenza virus replication. (See Table 3 for relevant information).

\subsection{Host LncRNAs Directly Act on Viral Genes to Regulates Influenza Virus Replication}

It was found that the host lncRNA could directly target the virus gene and affect virus replication during the process of infection. IAV infection significantly induces two host lncRNAs (PAAN and IPAN) not involved in IFN regulation. LncRNA PAAN enhances the activity of viral RNA polymerase by promoting the assembly of the RNA polymerase complex of the influenza virus, and as a forward regulator of influenza virus replication, ensures the efficient synthesis of virus RNA. LncRNA PAAN synthesis is synchronized with IAV replication [85]. It has been demonstrated that the lncRNA IPAN gene can be hijacked by the IAV in the process of viral infection to assist IAV replication. By stably binding with the viral PB1 protein, the IPAN/PB1 complex forms, preventing the degradation of PB1 and facilitating effective IAV transcription and replication [86]. Lnc45 is a broad-spectrum antiviral factor. Infection with multiple subtypes of influenza viruses such as H5N1, H7N9, and H1N1 can significantly induce up-regulation of Lnc45 expression, and overexpression of Lnc45 can significantly inhibit replication of H1N1, H5N1, and H7N9 viruses. Lnc45 translocates to the cytoplasm from the nucleus during H5N1 virus infection and Lnc45 inhibits polymerase activity and nuclear accumulation NP and PA through its stem ring arms thereby impairs IAV replication [87].

\subsection{Host LncRNAs Indirectly Inhibit IAV Replication by Regulating Intracellular Signals}

Host lncRNAs inhibit IAV replication by regulating innate immune signaling pathways mediated by TLRs. The innate immune response mediated by TLRs includes several key factors, such as the expression and activation of PRRs, ISG expression, and IFN production [88]. LncRNA-155 promotes the innate immune response to viral infection by negatively regulating the expression of protein tyrosine phosphatase $1 \mathrm{~B}$ and mediating the high expression of IFN- $\beta$ and some key ISGs [89]. Silencing of IFN-stimulated lncRNA-ISR in A549 cells resulted in a significant increase in IAV replication, while the overexpression of ISRs decreased viral replication. IFN- $\beta$ treatment can induce the expression of ISRs. In 
hosts without type I IFN receptors, the expression of ISRs induced by viral infection is not significant, and ISRs are regulated by IFN- $\beta$ during the process of IAV infection. IFN- $\beta$ also has the ability to inhibit virus replication [90].

Host IncRNA inhibit the replication of IAV by regulating the innate immune response mediated by RLRs. The RLR-mediated innate immune response is an important pathway for lncRNAs to participate in the regulation and inhibition of IAV replication. When the virus invades, the intracellular "whistle" RIG-I recognizes the double-strand RNAs (dsRNAs), transmits antiviral signals through downstream mitochondrial antiviral-signaling (MAVS) proteins, and finally induces the expression of IFNs and proinflammatory cytokines. At the early stage of viral infection, lncRNA z3h7a in the cytoplasm binds to tripartite motif-containing protein 25 (TRIM25) and activates RIG-I. As a molecular scaffold, lncRNA z3h7a stabilizes the TRIM25/RIG-I interaction and enhances TRIM25-mediated K63 ubiquitylation of RIG-I. Thus, the downstream signaling of RIG-I and the antiviral innate immune response are promoted [91]. LncRNA-AVAN enhances k63 ubiquitination of RIG-I by binding with TRIM25. At the same time, IncRNA-AVAN is located $419 \mathrm{bp}$ upstream of forkhead box O3 (FOXO3a); it can improve the expression of FOXO3a through chromatin remodeling, promote neutrophil chemotaxis and recruitment, upregulate the expression of IL-8, and then activate antiviral immunity [92]. The novel lncRNA IVRPIE is a key modulator of the host antiviral response. IVRPIE participates in antiviral innate immunosuppressive IAV replication by promoting IFNs and ISGs. In addition, hnPNP-U interacts with IVRPIE to regulate IFN $\beta 1$ and ISG transcription by affecting the histone modifications of IRF1, IFN-induced protein with interferon-induced protein with tetratricopetide repeats 1 (IFIT1), IFIT3, Mx1, ISG15, and IFN-induced protein 44-like (IFI44L) [93]. RDUR is a multi-function IncRNA, on the one hand, it enhances host antiviral immunity by positively activating the IRF3 and upregulating ILF2/ILF3, thereby positively regulating the expression of IFNs and key ISGs. On the other hand, experiments demonstrate that deletion of RDUR promotes viral infection through downregulating some crucial antiviral genes but activating the NF- $\mathrm{KB}$-dependent inflammatory response, suggesting that virusinduced expression of RDUR may prevent the host from serious inflammation reaction possibly through a mechanism involving a negative feedback control of NF- $\mathrm{kB}$ activation and inflammation [94]. LncRNA EGOT, a long non-coding RNA induced by viral infection, can reduce viral replication by promoting the expression of IFNs through pathways such as PI3K/AKT, MAPKs, and NF- $\mathrm{kB}$. LncRNA EGOT also can affect cell autophagy by regulating expression of ATG7, ATG16L1, LC3II, and LC3 $[95,96]$. In the process of influenza virus infection, lnc-Cxcl2 could selectively inhibit the expression of Cxcl2 in mouse lung epithelial cells, but not in macrophages, which can attenuate inflammatory damage through feedback inhibition of lung epithelial cells chemokine expression and neutrophil recruitment [97].

\subsection{Host LncRNAs Indirectly Promote IAV Replication by Regulating Intracellular Signaling}

Influenza virus negatively regulates the antiviral immune response mediated by TLRs by inducing the expression of intracellular lncRNA [98]. A/WSN/1933, A/Oklahoma/3052/ 09, and type I IFNs can induce the significant expression of lncRNA PSMB8-AS1, inhibit the expression of lncRNA PSMB8-AS1, and effectively reduce the expression of IAV genes and the release of progeny IAV virions [99]. As an IFN-inducible gene, IncRNA-MxA is significantly induced and up-regulated during IAV infection. It negatively regulates the transcription of IFN- $\beta$ by forming a triplet with the IFN- $\beta$ promoter and plays an important role in the negative feedback loop involved in maintaining immune homeostasis as a negative regulator of the antiviral immune response [100].

RLRs signaling pathway plays a key role in the escape process of the influenza virus. After the influenza virus invades the body, viral proteins will degrade or inactivate RIG-I, MDA5, MAVS, and other monitoring proteins, thus avoiding the immune mechanism of the body [101]. The lncRNA NRAV and lncRNA VIN have been shown to increase viral replication. The expression level of NRAV was significantly decreased in cells infected with 
IAV. Overexpression of NRAV significantly promoted the replication and virulence of IAV, and knockout of NRAV decreased the replication and virulence of IAV. By changing the histone modification levels of IFITM3 and MxA promoters in key ISGs, NRAV activated H3K4me3 and inhibited H3K27me3, thus negatively regulating the gene transcription of IFITM3 and MxA. Through RNA pull-down and RNA immunoprecipitation (RIP) tests, it was also found that NRAV specifically interacted with the transcription factor zonula occludens-1 nucleic acid-binding protein (ZONAB) to affect the transcriptional regulation of MxA [102]. VIN is a virus-induced lncRNA. Low expression of VIN can inhibit viral replication and significantly reduce viral gene expression. Nuclear localization suggests that VIN and PSMB8-AS1 play a role in the transcription and replication of IAV RNA genomes [103]. lncRNA-lsm3b is an IFN-induced lncRNA. In the late stage of mouse macrophage infection, lnc-lsm3b acts as bait for RIG-I to compete with viral RNA for RIG-I monomer binding, restricting the conformational change in RIG-I protein and preventing further activation of RIG-I. Lnc-lsm3b also reduces IFN-I production to maintain immune homeostasis, and its overexpression in L929 cells interferes with TRIM25-mediated K63 junction ubiquitination of RIG-I during viral infection [104].

A new study found that the lncRNA ACOD1 promotes IAV replication by regulating cell metabolism [105]. LncRNA ACOD1 can be induced by a variety of viruses including IAV. It can directly combine with the metabolic enzyme glutamate-oxaloacetate transaminase (GOT2) in the cytoplasm, improve the catalytic activity of the enzyme, enhance the production of key metabolites required for viral replication, and promote the replication of the influenza virus in A549 cells [106].

The above studies showed that in addition to host lncRNAs participating in the innate immune response pathway to regulate the replication of IAV, influenza viruses can also use host-encoded lncRNAs to negatively regulate the innate immune response of the host.

\section{Other Host Non-Coding RNAs Regulate the Replication of Influenza A Virus}

Vault RNA (vtRNA) is a class of non-coding RNAs in the Vault ribosome complex, which plays a key role in the process of influenza virus infection and replication [107]. PKR is an important part of host innate immunity against viral infection, and the H1N1 influenza virus can induce high expression of vtRNAs in host cells. Silencing of vtRNAs in A549 cells significantly inhibited IAV replication, while overexpression of vtRNAs significantly promoted viral replication. Further studies showed that vtRNAs promote viral replication by inhibiting PKR activation and the subsequent antiviral IFN response. Viral NS1 protein was shown to be an inducer that triggered the upregulation of vtRNAs. In addition, the effective inhibition of PKR by NS1 during IAV infection requires increased expression of vtRNAs [108] (See Table 3 for relevant information). These studies demonstrated that vtRNAs, as host factors utilized by viruses, play an important role in influenza virus antagonism against host innate immunity. However, the molecular mechanism by which NS1 regulates the expression of vtRNAs remains to be studied.

Virus-host interactions are complicated processes, and multiple cellular proteins promote or inhibit viral replication through different mechanisms. CircRNAs are a newly discovered class of endogenous regulatory RNAs that are widely expressed and characterized by a covalent closed-loop structure without a $5^{\prime}$ cap or $3^{\prime}$ tail. In recent years, a growing number of circRNAs have been reported to play important roles in a variety of human diseases, including in dynamic interactions between the virus and host [109-113]. H1N1 infection induced the overexpression of circ-GATAD2A. With circ-GATAD2A knockout in the A549 cell line, autophagy was enhanced while H1N1 replication was suppressed. In contrast, overexpression of circ-GATAD2A in the A549 cell line suppressed autophagy and promoted H1N1 replication. Further research showed that circ-GATAD2A interacted with vacuolar protein sorting 34 (VPS34) and the inhibition of autophagy promoted the replication of H1N1 [114]. The researchers found and identified a novel intron circRNA named AIVR that was upregulated in A549 cells infected by the influenza virus. Silencing AIVR significantly promoted the replication of the influenza virus in A549 cells, as a miRNA 
sponge, AIVR is mainly located in the cytoplasm. It plays an antiviral role by absorbing miRNA and promoting the expression of CREBBP so as to promote the expression of IFN- $\beta$ [113].

Table 3. Regulation of influenza A virus replication by host lncRNAs.

\begin{tabular}{|c|c|c|c|c|c|c|c|}
\hline \multicolumn{2}{|c|}{ LncRNA } & Target Gene ${ }^{a}$ & Cell Type & $\begin{array}{l}\text { Regulation } \\
\text { Direction } b\end{array}$ & Virus & $\begin{array}{c}\text { Induced } \\
\text { Expression }\end{array}$ & References \\
\hline \multicolumn{2}{|c|}{ LncRNA IPAN } & PB1 & A549 & Promote & $\begin{array}{c}\text { H1N1 } \\
\text { (A/WSN/33) }\end{array}$ & UP & [86] \\
\hline \multicolumn{2}{|c|}{ LncRNA PAAN } & PA & A549 & Promote & $\begin{array}{c}\text { H1N1 } \\
(\mathrm{A} / \mathrm{PR} / 8 / 34)\end{array}$ & UP & [85] \\
\hline $\begin{array}{l}\text { Signaling } \\
\text { pathways }\end{array}$ & LncRNA & Target gene ${ }^{\mathrm{e}}$ & Cell type & $\begin{array}{l}\text { Regulation } \\
\text { direction } b\end{array}$ & Virus & $\begin{array}{l}\text { Induced } \\
\text { expression }\end{array}$ & References \\
\hline \multirow{10}{*}{ RLRs } & LncRNA NRAV & ZONAB & A549 & Promote & $\begin{array}{c}\text { H1N1 } \\
\text { (A/WSN/33) }\end{array}$ & DOWN & [115] \\
\hline & LncRNA Lsm3b & RIG-I & L929 & Promote & $\begin{array}{c}\text { H1N1 } \\
\text { (A/ } \\
\text { Puerto } \\
\text { Rico } \\
\text { /8/1934) }\end{array}$ & UP & [104] \\
\hline & LncRNA VIN & Nuclear & A549 & Promote & $\begin{array}{c}\text { H1N1 } \\
\text { (A/WSN/33) }\end{array}$ & UP & [103] \\
\hline & LncRNA-155 & РTP1B & A549 & Inhibition & $\begin{array}{c}\text { H1N1 } \\
\text { (A/Puerto Ri-co/8/1934) }\end{array}$ & UP & [89] \\
\hline & $\begin{array}{l}\text { LncRNA } \\
\text { IVPRIE }\end{array}$ & RIG-I & A549 & Inhibition & $\begin{array}{c}\text { H1N1 } \\
\text { (A/Puerto Ri-co/8/1934) }\end{array}$ & UP & [93] \\
\hline & $\begin{array}{l}\text { LncRNA } \\
\text { NEAT1 }\end{array}$ & SFPQ & Hela & Inhibition & $\begin{array}{c}\text { H1N1 } \\
\text { (A/WSN/33) }\end{array}$ & UP & [116] \\
\hline & LncRNA ISG20 & miR-326 & $\begin{array}{c}\text { A549 } \\
\text { HEK293T }\end{array}$ & Inhibition & $\begin{array}{c}\text { H1N1 } \\
\text { (A/Puerto Ri-co/8/34) }\end{array}$ & UP & [117] \\
\hline & LncRNA ISR & IFN- $\beta$ & A549 & Inhibition & $\begin{array}{c}\text { H1N1 } \\
\text { (A/California/04/2009) }\end{array}$ & UP & [90] \\
\hline & LncRNA AVAN & TRIM25 & A549 & Inhibition & $\begin{array}{c}\text { H7N9 } \\
\text { (A/Hebei/01/2013) }\end{array}$ & UP & [92] \\
\hline & $\begin{array}{l}\text { lncRNA } \\
\text { IFITM4P }\end{array}$ & $\operatorname{miR}-24-3 p$ & A549 & Inhibition & $\begin{array}{c}\text { H1N1 } \\
\text { (A/Shanghai- } \\
\text { Jiading/SWL1970/2015) }\end{array}$ & UP & [118] \\
\hline \multirow{3}{*}{ TLRs } & $\begin{array}{l}\text { LncRNA } \\
\text { TSPOAP1 }\end{array}$ & $N F-\kappa B$ & A549 & Promote & $\begin{array}{c}\text { H1N1 } \\
\text { (A/PR/8/34) } \\
\text { H3N2 } \\
\text { (A/Lufang/9/93) }\end{array}$ & UP & [119] \\
\hline & LncRNA-MxA & IFN- $\beta$ & A549 & Promote & $\begin{array}{c}\text { H1N1 } \\
\text { (A/WSN/33) }\end{array}$ & UP & [100] \\
\hline & PSMB8-AS1 & IFN & A549 & Promote & $\begin{array}{c}\text { H1N1 } \\
\text { (A/Puerto Ri-co/8/34) }\end{array}$ & UP & [99] \\
\hline $\begin{array}{c}\text { Cell } \\
\text { metabolism }\end{array}$ & $\begin{array}{l}\text { LncRNA- } \\
\text { ACOD1 }\end{array}$ & GOT2 & A549 & Promote & $\begin{array}{c}\text { H1N1 } \\
\text { (A/WSN/33) }\end{array}$ & UP & [106] \\
\hline \multirow[b]{2}{*}{$N F-\kappa B$} & LncRNA TUG1 & miR-145-5p & DHBE & Inhibition & H3N2 & UP & [120] \\
\hline & LncRNA RDUR & $\begin{array}{l}\text { RIG-I/MAVS } \\
\text { /NF- } \mathrm{BB}\end{array}$ & A549 & Inhibition & $\begin{array}{c}\text { H1N1 } \\
\text { (A/Shanghai-Jiad- } \\
\text { ing/SWL1970/2015) }\end{array}$ & UP & [94] \\
\hline \multicolumn{8}{|c|}{ Other ncRNAs in the host regulate influenza A virus replication } \\
\hline $\begin{array}{l}\text { Signaling } \\
\text { pathways }\end{array}$ & NcRNA & Target gene ${ }^{e}$ & Cell type & $\begin{array}{l}\text { Regulation } \\
\text { direction }^{b}\end{array}$ & Virus & $\begin{array}{c}\text { Induced } \\
\text { expression }\end{array}$ & References \\
\hline $\begin{array}{l}\text { Post } \\
\text { transcriptional } \\
\text { regulation }\end{array}$ & Circ_0050463 & $\begin{array}{l}\operatorname{microRNA}-33 b- \\
5 \mathrm{p}\end{array}$ & A549 & Promote & $\begin{array}{c}\text { H1N1 } \\
\text { (A/Lufang/9/93) }\end{array}$ & UP & [121] \\
\hline $\begin{array}{l}\text { Autophagy } \\
\text { regulation }\end{array}$ & Circ-GATAD2A & VPS34 & A549 & Promote & $\begin{array}{c}\text { H1N1 } \\
\text { (A/ } \\
\text { Puerto Ri-co } \\
/ 8 / 34)\end{array}$ & UP & [114] \\
\hline PKR & vtRNAs & NS1 & A549 & Promote & $\begin{array}{c}\text { H1N1 } \\
\text { (A/WSN/33) }\end{array}$ & UP & [108] \\
\hline
\end{tabular}

a: LncRNAs directly target key genes of viruses; ${ }^{\mathrm{b}}$ : ncRNA mediated regulation of influenza virus replication; ${ }^{\mathrm{c}}$ : induced expression of ncRNA after influenza virus infection; ${ }^{\mathrm{d}}$ : signaling pathways involved in regulation by ncRNA; : target genes bound by ncRNAs. 


\section{Host Non-Coding RNAs Regulate the Replication of Other Influenza Virus}

Influenza B viruses have a limited host range compared to influenza A viruses, the mutation rate was low, and is not easy to cause a pandemic. In the past few decades, there have been many studies on the interaction between host and influenza B virus Host noncoding RNA plays an important role in directly or indirectly regulating the replication of influenza B virus. (See Table 4 for relevant information).

According to reports, the hsa-miR-30e-3p is one of the miRNAs regulating influenza $B$ virus infection, it is able to directly inhibit the expression of NA, NP genes of the influenza B virus (influenza B virus B/Thailand/CU-B5522/2011 representing the Victoria lineage) [122]. Replication and transport of Zika virus (ZIKV) and porcine reproductive and respiratory syndrome virus (PRRSV) in host cells require karyopherin alpha 6 (kpna6). In MDCK cells infected with influenza B virus (Victoria lineage (B/Thailand/CU-B5522/2011) or Yamagata lineage (B/Massachusetts/2/2012)), five miRNAs, including cfa-miR-197, cfa-miR-215, cfa-miR-361, cfa-miR-1841 and cfa-miR-1842, were significantly upregulated. The cfa-miR-197 mediates KPNA6 silencing by specifically binding to the 3'-UTR (GUGGUGA/UGGUGAA) of KPNA6. Therefore, this miRNA can inhibit the replication of the influenza B virus [123]. In chicken embryos infected with the influenza B virus, the expression level of miRNA induced by viral infection in the spleen was higher than in lungs, including miR-34c, $-34 b,-1 b,-1 a,-206$, and -499 . These miRNAs are also induced by infection of avian influenza virus, and most of them are involved in regulating immune responses (miR-34c, $-34 b,-1 b,-1 a$ and -206$)$. Studies have shown that gga-miR-30d inhibited the replication of IBV by targeting ubiquitin-specific peptidase 47 (USP47) in HD11 cells. However, also, in HD11 cells miR-146a-5p promoted IBV replication by targeting interleukin 1 receptor-associated kinase 2 (IRAK2) and TNF receptor superfamily member 18 (TNFRSF18) [123,124]. On this basis, the researchers further analyzed the changes of lncRNAs in IBV-infected HD11 cells and mapped the competitive endogenous RNA (ceRNA) regulation network of lncRNA-microRNA-mRNA, and the researchers also found that IncRNA MSTRG.21445.2 may regulate IBV infection by competing for gga-miR-30d and miR-146a-5p for mRNA with USP47, IRAK2, and TNFRSF18. These results provide new insights into the relationship between host non-coding RNA and replication of IBV, but most of the results are just based on bioinformatics analysis. Therefore, these findings should be further confirmed by laboratory studies [125].

Influenza $C$ virus is a common pathogen of acute respiratory diseases, and Children are susceptible to the influenza $C$ virus. Influenza $D$ is a newly discovered virus in cattle and pigs, which can cause mild to moderate respiratory diseases and target the upper and lower respiratory tract. IDV and ICV have about 50\% homology. The current studies on these two influenza viruses focus on the interaction between virus and host proteins. For example, the NS1 of ICV and IDV, similar to the NS1 of IBV and IAV, can be overexpressed in the infected host cells and inhibit the IFN function of the host cells; ANP32A-mediated influenza virus replicase assembly [126]; TMPRSS2 protein cleaves the HE of ICV and activates ICV [127]. However, there are few reports on the regulation of type $C$ and type D influenza viruses by host non-coding RNA. It is believed that there will be more new research progress in this direction with in-depth research and understanding of the infection mechanism of type $C$ and type $D$ influenza viruses in the future. 
Table 4. Regulation of miRNA on replication of influenza viruses other than influenza A virus.

\begin{tabular}{|c|c|c|c|c|c|c|c|}
\hline miRNA & Target Gene ${ }^{a}$ & Cell Type & $\begin{array}{l}\text { Regulation } \\
\text { Direction } b\end{array}$ & Virus & $\underset{\mathrm{c}}{\text { Induced Expression }}$ & $\begin{array}{l}\text { Binding Site } \\
\text { of Target } \\
\text { d }\end{array}$ & References \\
\hline $\begin{array}{l}\text { hsa-miR- } \\
\text { 30e-3p }\end{array}$ & NA, NP & A549 & Inhibition & $\begin{array}{c}\text { IBV } \\
\text { (Influ-enza B virus } \\
\text { B/Thailand/CU- } \\
\text { B5522/2011 } \\
\text { representing the } \\
\text { Vic-toria lineage) }\end{array}$ & UP & $\begin{array}{l}\text { GAUGUCU } \\
\text { GAACUGAAA }\end{array}$ & [122] \\
\hline $\begin{array}{c}\text { Signaling } \\
\text { pathways }\end{array}$ & miRNA & Target gene ${ }^{\mathrm{f}}$ & Cell type & $\begin{array}{l}\text { Regulation } \\
\text { direction }^{b}\end{array}$ & Virus & $\begin{array}{c}\text { Induced } \\
\text { expression }{ }^{\mathrm{c}}\end{array}$ & References \\
\hline \multirow[t]{3}{*}{ TLRs } & cfa-miR-197 & KPNA6 & MDCK & Inhibition & $\begin{array}{c}\text { IBV } \\
\text { Victoria lineage } \\
\text { (B/Thailand/CU- } \\
\text { B5522/2011), or } \\
\text { Yamagata lineage } \\
\text { (B/Massa } \\
\text { Chu-setts/2/2012) }\end{array}$ & UP & [128] \\
\hline & gga-miR-30d & USP47 & HD11 & Inhibition & $\begin{array}{c}\text { IBV } \\
\text { (Beaudette strain) }\end{array}$ & DOWM & [124] \\
\hline & $\begin{array}{c}\text { gga-miR-146a- } \\
5 p\end{array}$ & $\begin{array}{l}\text { IRAK2, } \\
\text { TNFRSF18 }\end{array}$ & chickens & promote & $\begin{array}{c}\text { IBV } \\
\text { (Beaudette strain) }\end{array}$ & UP & [123] \\
\hline
\end{tabular}

${ }^{a}$ : ncRNAs target key genes; ${ }^{b}$ : ncRNA mediated regulation of influenza virus replication; ${ }^{c}$ : induced expression of ncRNA after influenza virus infection; ${ }^{\mathrm{d}}$ : sequences of miRNA binding site of target $\left(5^{\prime}-3^{\prime}\right)$; ${ }^{\mathrm{e}}$ : signaling pathways involved in regulation by ncRNA; ${ }^{\mathrm{f}}$ : target genes bound by ncRNAs.

\section{Discussion}

In recent years, non-coding RNAs have attracted extensive attention from researchers. In this paper, through a comprehensive analysis of relevant studies on the regulation of host non-coding RNAs involved in the replication of IAV, we found that host noncoding RNAs mainly regulate influenza virus replication directly and indirectly. Some of them play a role in inhibiting the replication and proliferation of the virus, while others assist the virus to escape the monitoring system of the host immune response and invade the host cells faster by interacting with the virus genes. This provides a new strategy for the development of anti-influenza drugs targeting key genes of the virus.

In addition to directly regulating the expression of influenza virus genes, host noncoding RNA can also participate in the coordination of intracellular signaling and the expression of antiviral factors, and indirectly regulate the replication of the influenza virus. With further research on non-coding RNAs, how these host non-coding RNAs regulate the expression of antiviral factors in the process of innate immune response and play an indirect role in the regulation of the replication and proliferation of influenza viruses will become clearer, and these non-coding RNAs will hopefully become new candidate drugs for anti-influenza virus research.

CeRNAs provide a new regulation mode for gene expression. Studies have shown that compared to simple miRNA-mRNA regulation, the ceRNA regulation network is more complex and generally consists of an integrated regulation network involving circRNAmiRNA-mRNA and lncRNA-miRNA-mRNA. Currently, studies on ceRNAs are mainly focused on their role in the regulation of tumor genesis, and there are few reports on how ceRNAs regulate influenza virus replication. LncRNAs and circRNAs have abundant miRNA binding sites, so they can bind the MERS of miRNAs, like a sponge, to form ceRNAs, prevent miRNAs from binding with target gene mRNAs, and regulate the expression of the target genes (see Figure 2 for relevant information) [129]. A new study found that as a ceRNA, the lncRNA IFITM4P can be induced and expressed by multiple H1N1 strains and other pathogenic viruses. In vitro and in vivo experiments demonstrated that IFITM4P can participate in the natural immune antiviral response through the lncRNA IFITM4PmiR-24-3p-IFITM1/2/3 regulatory network and is a potential antiviral host factor [118]. By analyzing the expression profile of lncRNAs before and after influenza virus infection, 
researchers found that the expression of lnc-ISG20 in infected cells was significantly upregulated. IAV infection triggers the transcription of type I interferons, such as IFN- $\beta$. IFN- $\beta$ stimulates the transcription of downstream genes (ISG20 and lnc-ISG20). miR-326 inhibited the translation of ISG20 by targeting the $3^{\prime}$ UTR of ISG20 mRNA, thus promoting the replication of the virus. Lnc-ISG20 acts as a ceRNA by reducing miR-326 binding to target ISG20 mRNA and enhances the translation of ISG20, which in turn inhibits IAV replication. [117]. The NF- $\mathrm{kB}$ pathway is positively regulated by the lncRNA TUG1 and negatively regulated by miR-145-5p. Influenza virus can induce airway hypersensitivity in chronic obstructive pulmonary disease (COPD). TUG1 positively regulates airway inflammation mediated by the NF-KB pathway by binding miR-145-5p. Inhibition of TUG1 can inhibit the expression of the NF- $\mathrm{KB}$ pathway and its downstream pro-inflammatory cytokines IL-1 $\beta$ and TNF- $\alpha$, and significantly reduce airway inflammation [120]. LncRNAAABR07020987.1 positively affected the expression of IL-17A by acting as a ceRNA to compete with IL-17A mRNA for binding sites of mo-miR-369-3p [130]. Similarly, in A549 cells infected with IAV, Circ-0050463 an endogenous miRNA-33b-5p sponge, can isolate and inhibit the activity of miRNA-33b-5p, activate the expression of eukaryotic translation elongation factor 1 alpha 1 (EEF1A1), and promote IAV replication through the mir-33b$5 p / E E F 1 A 1$ axis [121]. These results indicate that compared with the miRNA regulatory network, the ceRNA regulatory network is more delicate and complex, and involves more RNA molecules, including mRNA, IncRNA, miRNA, and circRNA, which provides a new perspective for researchers to conduct transcriptome studies. This knowledge is also helpful to explain some biological phenomena more comprehensively and deeply.
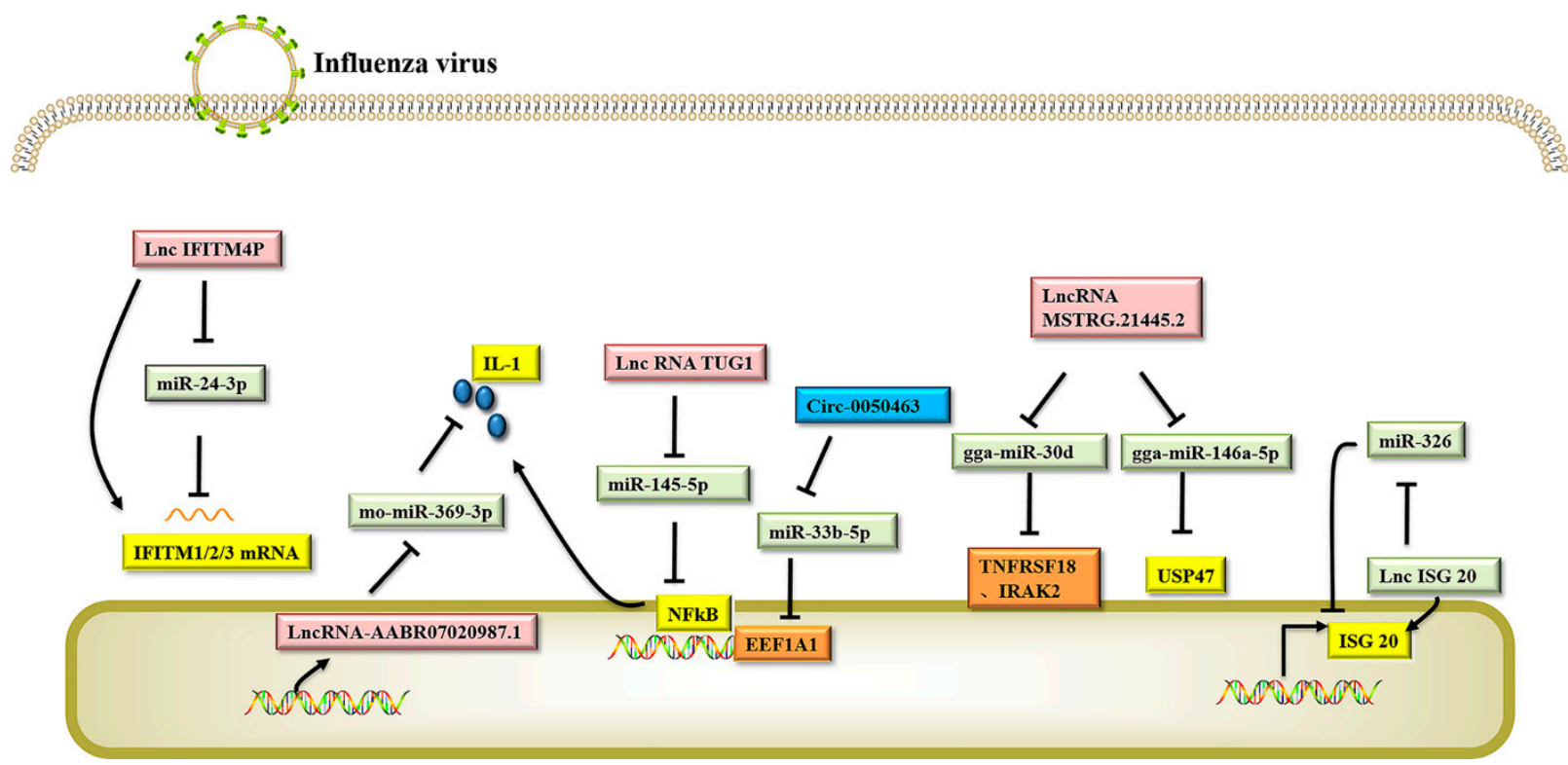

Figure 2. Competitive endogenous RNAs involved in regulating influenza virus replication. The ceRNA interaction network has more complex regulatory mechanisms compared to the simple host non-coding RNA regulating influenza virus replication. The regulatory process involves mutual regulation between non-coding RNA, and also non-coding RNA interaction with host proteins, ultimately enabling regulation of influenza virus replication through a series of complex regulatory mechanisms. (The Pink/blue boxes indicate lncRNA/circRNA that can bind to microRNA; green box indicates the microRNA that binds to the key antiviral protein of the host; The yellow /orange box indicates the host protein that can inhibit/promote the expression of influenza virus during antiviral process).

In the face of cunning and changeable influenza virus, effectively activating the immune response to the conserved domains of the virus is an effective method to realize a broad-spectrum influenza vaccine [131]. Specific antibodies demonstrated in mouse, ferret 
models targeting viral protein conserved domains, such as matrix protein M2 or HA stem domains, can be effective to treat or prevent infection of different influenza strains [132]. Studies have shown that it is promising to enhance the immune protective effect of vaccines by using host non-coding RNA. For example, murine models have demonstrated that docetaxel can upregulate the Th1, Th2 immune responses, and has an influenza A H1N1 cleavage vaccine adjuvant effect. While the enhanced immune response may be related to the upregulation of miR-155 expression as detected in docetaxel-stimulated RAW264.7 cells [133]. Under direct regulation, miRNA can inhibit virus replication by binding virus mRNA. For example, inserting miR-let-7b into the PB1 gene of the H1N1 influenza virus can reduce the replication and proliferation ability of the virus in cells and animals [78]. In A549 cells, hsa-miR-1-3p decreases the expression of NP genes and suppresses replication of PR8 and H3N2 [134]. While miRNA-192-5p was inserted into the nuclear protein (NP) genomic fragment of the influenza virus to prepare live attenuated vaccines, cells and mice vaccinated with miRNA showed higher survival compared with general vaccine [135]. This research evidence suggests that the modification of key viral segments with host noncoding RNA as a strategy can be used to study and develop live-attenuated influenza vaccines.

In conclusion, host non-coding RNAs affect the process of viral infection by regulating the expression of host or virus-related genes and play an important role in the complex relationship between the host and virus regulation, facilitating a state of balance between the virus and host. The relationship between non-coding RNAs and viral infection still has broad research prospects. However, the mechanism of non-coding RNAs in influenza virus infection remains to be further studied. On the one hand, the current research mainly focuses on the function of non-coding RNAs in influenza virus infection, and it is not clear whether non-coding RNAs play a role in the escape process of influenza virus. On the other hand, influenza virus infection can induce the differential expression of a large number of non-coding RNAs in host cells. Only a few studies have confirmed their function in the interaction between virus and host. The role of many non-coding RNAs in the process of influenza virus infection is still poorly understood. Further clarification of the interaction mechanism will help researchers better understand the precise regulatory mechanism of these host non-coding RNAs during the process of IAV infection. It will also help provide promising targets for the development of antiviral strategies by reducing key regulatory factors associated with viral infection and enhancing innate immune responses.

Author Contributions: Y.L. and Z.L. designed the concept of the project and wrote the manuscript; S.G., G.L., Z.Q. (Zhenyu Qiu), J.W., D.Y., X.T., Z.Q. (Ziling Qiao) and Z.M. writing-review and editing. All authors contributed to the article and approved the submitted version. All authors have read and agreed to the published version of the manuscript.

Funding: This research was funded and supported by the Fundamental Research Funds for the Central Universities (31920210033), the Science and technology project of Gansu Province (20JR10RA121) (18JR2JA004), the National Natural Science Foundation of China (32160164).

Conflicts of Interest: The authors declare that the research was conducted in the absence of any commercial or financial relationships that could be construed as a potential conflict of interest.

\section{References}

1. Ciminski, K.; Chase, G.P.; Beer, M.; Schwemmle, M. Influenza A Viruses: Understanding Human Host Determinants. Trends Mol. Med. 2021, 27, 104-112. [CrossRef] [PubMed]

2. Dadonaite, B.; Gilbertson, B.; Knight, M.L.; Trifkovic, S.; Rockman, S.; Laederach, A.; Brown, L.E.; Fodor, E.; Bauer, D.L.V. The structure of the influenza A virus genome. Nat. Microbiol. 2019, 4, 1781-1789. [CrossRef]

3. Harrington, W.N.; Kackos, C.M.; Webby, R.J. The evolution and future of influenza pandemic preparedness. Exp. Mol. Med. 2021, 53, 737-749. [CrossRef]

4. Podstawka, J.; Sinha, S.; Hiroki, C.H.; Sarden, N.; Granton, E.; Labit, E.; Kim, J.H.; Andonegui, G.; Lou, Y.; Snarr, B.D.; et al. Marginating transitional B cells modulate neutrophils in the lung during inflammation and pneumonia. J. Exp. Med. 2021, 218, e20210409. [CrossRef]

5. Jiang, Z.; Wei, F.; Zhang, Y.; Wang, T.; Gao, W.; Yu, S.; Sun, H.; Pu, J.; Sun, Y.; Wang, M.; et al. IFI16 directly senses viral RNA and enhances RIG-I transcription and activation to restrict influenza virus infection. Nat. Microbiol. 2021, 6, 932-945. [CrossRef] 
6. Vogel, O.A.; Han, J.; Liang, C.; Manicassamy, S.; Perez, J.T.; Manicassamy, B.; Bukreyev, A. The p150 Isoform of ADAR1 Blocks Sustained RLR signaling and Apoptosis during Influenza Virus Infection. PLoS Pathog. 2020, 16, e1008842. [CrossRef]

7. Kandasamy, M.; Suryawanshi, A.; Tundup, S.; Perez, J.T.; Schmolke, M.; Manicassamy, S.; Manicassamy, B. RIG-I Signaling Is Critical for Efficient Polyfunctional T Cell Responses during Influenza Virus Infection. PLoS Pathog. 2016, 12, e1005754. [CrossRef]

8. Sun, N.; Li, C.; Li, X.; Deng, Y.; Jiang, T.; Zhang, N.; Zu, S.; Zhang, R.; Li, L.; Chen, X.; et al. Type-IInterferon-Inducible SERTAD3 Inhibits Influenza A Virus Replication by Blocking the Assembly of Viral RNA Polymerase Complex. Cell Rep. 2020, $33,108342$. [CrossRef]

9. Jung, H.J.; Park, S.H.; Cho, K.M.; Jung, K.I.; Cho, D.; Kim, T.S. Threonyl-tRNA Synthetase Promotes T Helper Type 1 Cell Responses by Inducing Dendritic Cell Maturation and IL-12 Production an NF-kB Pathway. Front. Immunol. 2020, 11, 571959. [CrossRef]

10. Hornick, E.E.; Dagvadorj, J.; Zacharias, Z.R.; Miller, A.M.; Langlois, R.A.; Chen, P.; Legge, K.L.; Bishop, G.A.; Sutterwala, F.S.; Cassel, S.L. Dendritic cell NLRC4 regulates influenza A virus-specific CD4 T cell responses through FasL expression. J. Clin. Investig. 2019, 129, 2888-2897. [CrossRef]

11. Mohapatra, S.; Pioppini, C.; Ozpolat, B.; Calin, G.A. Non-coding RNAs regulation of macrophage polarization in cancer. Mol. Cancer 2021, 20, 24. [CrossRef] [PubMed]

12. Zhao, X.; Jie, X.; Gao, Y.; Nie, B.; Jiang, H. Long non-coding RNA CACNA1G-AS1 promotes proliferation and invasion and inhibits apoptosis by regulating expression of miR-205 in human keloid fibroblasts. Biosci. Rep. 2020, 40, BSR20192839. [CrossRef]

13. Lou, M.; Tang, X.; Wang, G.; He, J.; Luo, F.; Guan, M.; Wang, F.; Zou, H.; Wang, J.; Zhang, Q.; et al. Long noncoding RNA BS-DRL1 modulates the DNA damage response and genome stability by interacting with HMGB1 in neurons. Nat. Commun. 2021, 12, 4075. [CrossRef]

14. Xie, C.; Zhang, L.Z.; Chen, Z.L.; Zhong, W.J.; Fang, J.H.; Zhu, Y.; Xiao, M.H.; Guo, Z.W.; Zhao, N.; He, X.; et al. A hMTR4PDIA3P1-miR-125/124-TRAF6 Regulatory Axis and Its Function in NF kappa B Signaling and Chemoresistance. Hepatology 2020, 71, 1660-1677. [CrossRef]

15. Liu, R.; Lu, Z.; Gu, J.; Liu, J.; Huang, E.; Liu, X.; Wang, L.; Yang, J.; Deng, Y.; Qian, J.; et al. MicroRNAs 15A and 16-1 Activate Signaling Pathways That Mediate Chemotaxis of Immune Regulatory B cells to Colorectal Tumors. Gastroenterology 2018, 154, 637-651. [CrossRef] [PubMed]

16. Gaur, A.B.; Holbeck, S.L.; Colburn, N.H.; Israel, M.A. Downregulation of Pdcd4 by mir-21 facilitates glioblastoma proliferation in vivo. Neuro-oncology 2011, 13, 580-590. [CrossRef]

17. Zhang, Y.; Li, B.; Bai, Q.; Wang, P.; Wei, G.; Li, Z.; Hu, L.; Tian, Q.; Zhou, J.; Huang, Q.; et al. The lncRNA Snhg1-Vps13D vesicle trafficking system promotes memory CD8 T cell establishment via regulating the dual effects of IL-7 signaling. Signal Transduct. Target. Ther. 2021, 6, 126. [CrossRef]

18. Khatun, M.; Sur, S.; Steele, R.; Ray, R.; Ray, R.B. Inhibition of Long Noncoding RNA Linc-Pint by Hepatitis C Virus in Infected Hepatocytes Enhances Lipogenesis. Hepatology 2021, 74, 41-54. [CrossRef] [PubMed]

19. Zhao, X.; Fan, H.; Chen, X.; Zhao, X.; Wang, X.; Feng, Y.; Liu, M.; Li, S.; Tang, H. Hepatitis B Virus DNA Polymerase Restrains Viral Replication Through the CREB1/HOXA Distal Transcript Antisense RNA Homeobox A13 Axis. Hepatology 2021, 73, 503-519. [CrossRef]

20. Sui, B.; Chen, D.; Liu, W.; Wu, Q.; Tian, B.; Li, Y.; Hou, J.; Liu, S.; Xie, J.; Jiang, H.; et al. A novel antiviral lncRNA, EDAL, shields a T309 O-GlcNAcylation site to promote EZH2 lysosomal degradation. Genome Biol. 2020, 21, 228. [CrossRef] [PubMed]

21. Jin, X.; Xu, X.; Jiang, Y.; Liu, Y.; Sun, W.; Guo, Y.; Ren, Y.; Zuo, W.; Hu, X.; Huang, S.; et al. The endogenous retrovirus-derived long noncoding RNA TROJAN promotes triple-negative breast cancer progression via ZMYND8 degradation. Sci. Adv. 2019, 5, t9820. [CrossRef]

22. Xue, P.; Huang, S.; Han, X.; Zhang, C.; Yang, L.; Xiao, W.; Fu, J.; Li, H.; Zhou, Y. Exosomal miR-101-3p and miR-423-5p inhibit medulloblastoma tumorigenesis through targeting FOXP4 and EZH2. Cell Death Differ. 2021, 1-14. [CrossRef]

23. Yu, S.; Kim, V.N. A tale of non-canonical tails: Gene regulation by post-transcriptional RNA tailing. Nat. Rev. Mol. Cell Biol. 2020, 21, 542-556. [CrossRef]

24. Hanouskova, B.; Vavrova, G.; Ambroz, M.; Bousova, I.; Karlsen, T.A.; Skalova, L.; Matouskova, P. MicroRNAs mediated regulation of glutathione peroxidase 7 expression and its changes during adipogenesis. Biochim. Biophys. Acta Gene Regul. Mech. 2021, 194734. [CrossRef]

25. Zhang, X.; Chapat, C.; Wang, P.; Choi, J.; Li, Q.; Luo, J.; Wiebe, S.; Kim, S.; Robichaud, N.; Karam, I.F.; et al. microRNA-induced translational control of antiviral immunity by the cap-binding protein 4EHP. Mol. Cell 2021, 81, 1187-1199. [CrossRef]

26. Lin, J.; Xia, J.; Zhang, T.; Zhang, K.; Yang, Q. Genome-wide profiling of microRNAs reveals novel insights into the interactions between H9N2 avian influenza virus and avian dendritic cells. Oncogene 2018, 37, 4562-4580. [CrossRef]

27. Khongnomnan, K.; Makkoch, J.; Poomipak, W.; Poovorawan, Y.; Payungporn, S. Human miR-3145 inhibits influenza A viruses replication by targeting and silencing viral PB1 gene. Exp. Biol. Med. 2015, 240, 1630-1639. [CrossRef]

28. Song, L.; Liu, H.; Gao, S.; Jiang, W.; Huang, W. Cellular MicroRNAs Inhibit Replication of the H1N1 Influenza A Virus in Infected Cells. J. Virol. 2010, 84, 8849-8860. [CrossRef]

29. Cui, H.; Zhang, C.; Zhao, Z.; Zhang, C.; Fu, Y.; Li, J.; Chen, G.; Lai, M.; Li, Z.; Dong, S.; et al. Identification of cellular microRNA miR-188-3p with broad-spectrum anti-influenza A virus activity. Virol. J. 2020, 17, 12. [CrossRef] [PubMed] 
30. Wang, R.; Zhang, Y.Y.; Lu, J.S.; Xia, B.H.; Yang, Z.X.; Zhu, X.D.; Zhou, X.W.; Huang, P.T. The highly pathogenic H5N1 influenza A virus down-regulated several cellular MicroRNAs which target viral genome. J. Cell. Mol. Med. 2017, 21, 3076-3086. [CrossRef] [PubMed]

31. Ingle, H.; Kumar, S.; Raut, A.A.; Mishra, A.; Kulkarni, D.D.; Kameyama, T.; Takaoka, A.; Akira, S.; Kumar, H. The microRNA miR-485 targets host and influenza virus transcripts to regulate antiviral immunity and restrict viral replication. Sci. Signal. 2015, 8, a126. [CrossRef]

32. Jiang, W.; Wang, Q.; Chen, S.; Gao, S.; Song, L.; Liu, P.; Huang, W. Influenza A virus NS1 induces G0/G1 cell cycle arrest by inhibiting the expression and activity of RhoA protein. J. Virol. 2013, 87, 3039-3052. [CrossRef]

33. Bavagnoli, L.; Campanini, G.; Forte, M.; Ceccotti, G.; Percivalle, E.; Bione, S.; Lisa, A.; Baldanti, F.; Maga, G. Identification of a novel antiviral micro-RNA targeting the NS1 protein of the H1N1 pandemic human influenza virus and a corresponding viral escape mutation. Antivir. Res. 2019, 171, 104593. [CrossRef]

34. Zhou, Z.; Li, X.; Liu, J.; Dong, L.; Chen, Q.; Liu, J.; Kong, H.; Zhang, Q.; Qi, X.; Hou, D.; et al. Honeysuckle-encoded atypical microRNA2911 directly targets influenza A viruses. Cell Res. 2015, 25, 39-49. [CrossRef]

35. Williams, G.D.; Townsend, D.; Wylie, K.M.; Kim, P.J.; Amarasinghe, G.K.; Kutluay, S.B.; Boon, A.C.M. Nucleotide resolution mapping of influenza A virus nucleoprotein-RNA interactions reveals RNA features required for replication. Nat. Commun. 2018, 9, 412-465. [CrossRef]

36. Xie, X.; Pang, M.; Liang, S.; Lin, Y.; Zhao, Y.; Qiu, D.; Liu, J.; Dong, Y.; Liu, Y. Cellular microRNAs influence replication of H3N2 canine influenza virus in infected cells. Vet. Microbiol. 2021, 257, 109083. [CrossRef]

37. Ma, Y.J.; Yang, J.; Fan, X.L.; Zhao, H.B.; Hu, W.; Li, Z.P.; Yu, G.C.; Ding, X.R.; Wang, J.Z.; Bo, X.C.; et al. Cellular microRNA let-7c inhibits M1 protein expression of the H1N1 influenza A virus in infected human lung epithelial cells. J. Cell. Mol. Med. 2012, 16, 2539-2546. [CrossRef]

38. Song, J.; Sun, H.; Sun, H.; Jiang, Z.; Zhu, J.; Wang, C.; Gao, W.; Wang, T.; Pu, J.; Sun, Y.; et al. Swine MicroRNAs ssc-miR-221-3p and ssc-miR-222 Restrict the Cross-Species Infection of Avian Influenza Virus. J. Virol. 2020, 94, e01700-20. [CrossRef] [PubMed]

39. Kumar, A.; Kumar, A.; Ingle, H.; Kumar, S.; Mishra, R.; Verma, M.K.; Biswas, D.; Kumar, N.S.; Mishra, A.; Raut, A.A.; et al. MicroRNA hsa-miR-324-5p Suppresses H5N1 Virus Replication by Targeting the Viral PB1 and Host CUEDC2. J. Virol. 2018, 92, e01057-18. [CrossRef]

40. Zhang, S.; Wang, R.; Su, H.; Wang, B.; Sizhu, S.; Lei, Z.; Jin, M.; Chen, H.; Cao, J.; Zhou, H. Sus scrofa miR-204 and miR-4331 Negatively Regulate Swine H1N1/2009 Influenza A Virus Replication by Targeting Viral HA and NS, respectively. Int. J. Mol. Sci. 2017, 18, 749. [CrossRef] [PubMed]

41. Langlois, R.A.; Albrecht, R.A.; Kimble, B.; Sutton, T.; Shapiro, J.S.; Finch, C.; Angel, M.; Chua, M.A.; Gonzalez-Reiche, A.S.; Xu, K.; et al. MicroRNA-based strategy to mitigate the risk of gain-of-function influenza studies. Nat. Biotechnol. 2013, 31, 844-847. [CrossRef]

42. Zhang, S.; Gu, D.; Ouyang, X.; Xie, W. Proinflammatory effects of the hemagglutinin protein of the avian influenza A (H7N9) virus and microRNAmediated homeostasis response in THP1 cells. Mol. Med. Rep. 2015, 12, 6241-6246. [CrossRef]

43. Li, Y.U.; Chan, E.Y.; Li, J.; Ni, C.; Peng, X.; Rosenzweig, E.; Tumpey, T.M.; Katze, M.G. MicroRNA Expression and Virulence in Pandemic Influenza Virus-Infected Mice. J. Virol. 2010, 84, 3023-3032. [CrossRef]

44. Zhang, X.; Dong, C.; Sun, X.; Li, Z.; Zhang, M.; Guan, Z.; Duan, M. Induction of the cellular miR-29c by influenza virus inhibits the innate immune response through protection of A20 mRNA. Biochem. Bioph. Res. Co. 2014, 450, 755-761. [CrossRef]

45. Pichulik, T.; Khatamzas, E.; Liu, X.; Brain, O.; Delmiro, G.M.; Leslie, A.; Danis, B.; Mayer, A.; Baban, D.; Ragoussis, J.; et al. Pattern recognition receptor mediated downregulation of microRNA-650 fine-tunes MxA expression in dendritic cells infected with influenza A virus. Eur. J. Immunol. 2016, 46, 167-177. [CrossRef]

46. Bamunuarachchi, G.; Yang, X.; Huang, C.; Liang, Y.; Guo, Y.; Liu, L. MicroRNA-206 inhibits influenza A virus replication by targeting tankyrase 2. Cell. Microbiol. 2021, 23, e13281. [CrossRef] [PubMed]

47. Wolf, S.; Wu, W.; Jones, C.; Perwitasari, O.; Mahalingam, S.; Tripp, R.A.; Chan, M.C. MicroRNA Regulation of Human Genes Essential for Influenza A (H7N9) Replication. PLoS ONE 2016, 11, e155104. [CrossRef]

48. Goncalves-Alves, E.; Saferding, V.; Schliehe, C.; Benson, R.; Kurowska-Stolarska, M.; Brunner, J.S.; Puchner, A.; Podesser, B.K.; Smolen, J.S.; Redlich, K.; et al. MicroRNA-155 Controls T Helper Cell Activation During Viral Infection. Front. Immunol. 2019, 10, 1367. [CrossRef] [PubMed]

49. Song, X.; Tan, S.; Wu, Z.; Xu, L.; Wang, Z.; Xu, Y.; Wang, T.; Gao, C.; Gong, Y.; Liang, X.; et al. HBV suppresses ZHX2 expression to promote proliferation of HCC through miR-155 activation. Int. J. Cancer 2018, 143, 3120-3130. [CrossRef]

50. Zhu, Z.; Teng, M.; Li, H.; Zheng, L.; Liu, J.; Yao, Y.; Nair, V.; Zhang, G.; Luo, J. Virus-encoded miR-155 ortholog in Marek's disease virus promotes cell proliferation via suppressing apoptosis by targeting tumor suppressor WWOX. Vet. Microbiol. 2021, 252, 108919. [CrossRef]

51. Shen, S.M.; Jiang, H.; Zhao, J.N.; Shi, Y. Down-regulation of miR-155 inhibits inflammatory response in human pulmonary microvascular endothelial cells infected with influenza A virus by targeting sphingosine-1-phosphate receptor 1 . Chin. Med. J. 2020, 133, 2429-2436. [CrossRef]

52. Woods, P.S.; Doolittle, L.M.; Rosas, L.E.; Nana-Sinkam, S.P.; Tili, E.; Davis, I.C. Increased expression of microRNA-155-5p by alveolar type II cells contributes to development of lethal ARDS in H1N1 influenza A virus-infected mice. Virology 2020, 545, 40-52. [CrossRef] [PubMed] 
53. Izzard, L.; Dlugolenski, D.; Xia, Y.; Mcmahon, M.; Middleton, D.; Tripp, R.A.; Stambas, J. Enhanced immunogenicity following miR-155 incorporation into the influenza A virus genome. Virus Res. 2017, 235, 115-120. [CrossRef]

54. Sayed, N.; Ospino, F.; Himmati, F.; Lee, J.; Chanda, P.; Mocarski, E.S.; Cooke, J.P. Retinoic Acid Inducible Gene 1 Protein (RIG1)-Like Receptor Pathway Is Required for Efficient Nuclear Reprogramming. Stem Cells 2017, 35, 1197-1207. [CrossRef] [PubMed]

55. Shang, J.; Zheng, Y.; Mo, J.; Wang, W.; Luo, Z.; Li, Y.; Chen, X.; Zhang, Q.; Wu, K.; Liu, W.; et al. Sox4 represses host innate immunity to facilitate pathogen infection by hijacking the TLR signaling networks. Virulence 2021, 12, 704-722. [CrossRef] [PubMed]

56. Zhao, L.; Zhu, J.; Zhou, H.; Zhao, Z.; Zou, Z.; Liu, X.; Lin, X.; Zhang, X.; Deng, X.; Wang, R.; et al. Identification of cellular microRNA-136 as a dual regulator of RIG-I-mediated innate immunity that antagonizes H5N1 IAV replication in A549 cells. Sci. Rep. 2015, 5, 14991. [CrossRef]

57. Gui, S.; Chen, X.; Zhang, M.; Zhao, F.; Wan, Y.; Wang, L.; Xu, G.; Zhou, L.; Yue, X.; Zhu, Y.; et al. Mir-302c mediates influenza A virus-induced IFN $\beta$ expression by targeting NF- $\mathrm{BB}$ inducing kinase. FEBS Lett. 2015, 589, 4112-4118. [CrossRef]

58. Chen, X.; Zhou, L.; Peng, N.; Yu, H.; Li, M.; Cao, Z.; Lin, Y.; Wang, X.; Li, Q.; Wang, J.; et al. MicroRNA-302a suppresses influenza A virus-stimulated interferon regulatory factor-5 expression and cytokine storm induction. J. Biol. Chem. 2017, 292, 21291-21303. [CrossRef]

59. Lin, X.; Yu, S.; Ren, P.; Sun, X.; Jin, M. Human microRNA-30 inhibits influenza virus infection by suppressing the expression of SOCS1, SOCS3, and NEDD4. Cell. Microbiol. 2020, 22, e13150. [CrossRef] [PubMed]

60. Liu, C.; Miao, Y.; Chen, R.; Zhang, Y.; Wu, H.; Yang, S.; Shang, L. STIM1 mediates IAV-induced inflammation of lung epithelial cells by regulating NLRP3 and inflammasome activation via targeting miR-223. Life Sci. (1973) 2021, 266, 118845. [CrossRef]

61. Yang, X.; Liang, Y.; Bamunuarachchi, G.; Xu, Y.; Vaddadi, K.; Pushparaj, S.; Xu, D.; Zhu, Z.; Blaha, R.; Huang, C.; et al. miR-29a is a negative regulator of influenza virus infection through targeting of the frizzled 5 receptor. Arch. Virol. 2021, 166, 363-373. [CrossRef]

62. Shi, J.; Feng, P.; Gu, T. MicroRNA-21-3p modulates FGF2 to facilitate influenza A virus H5N1 replication by refraining type I interferon response. Biosci. Rep. 2020, 40, BSR20200158. [CrossRef] [PubMed]

63. Xia, B.; Lu, J.; Wang, R.; Yang, Z.; Zhou, X.; Huang, P. miR-21-3p Regulates Influenza A Virus Replication by Targeting Histone Deacetylase-8. Front. Cell. Infect. Microbiol. 2018, 8, 175. [CrossRef]

64. Guo, M.; Li, F.; Ji, J.; Liu, Y.; Liu, F.; Zhao, Y.; Li, J.; Han, S.; Wang, Q.; Ding, G. Inhibition of miR-93 promotes interferon effector signaling to suppress influenza A infection by upregulating JAK1. Int. Immunopharmacol. 2020, 86, 106754. [CrossRef]

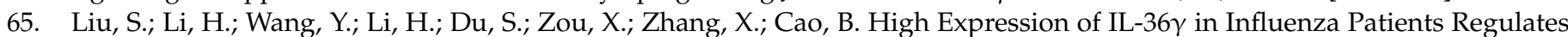
Interferon Signaling Pathway and Causes Programmed Cell Death During Influenza Virus Infection. Front. Immunol. 2020, 11, 552606. [CrossRef] [PubMed]

66. Hu, Y.; Jiang, L.; Lai, W.; Qin, Y.; Zhang, T.; Wang, S.; Ye, X. MicroRNA-33a disturbs influenza A virus replication by targeting ARCN1 and inhibiting viral ribonucleoprotein activity. J. Gen. Virol. 2016, 97, 27. [CrossRef] [PubMed]

67. Wang, K.; Lai, C.; Gu, H.; Zhao, L.; Xia, M.; Yang, P.; Wang, X. miR-194 Inhibits Innate Antiviral Immunity by Targeting FGF2 in Influenza H1N1 Virus Infection. Front. Microbiol. 2017, 8, 2187. [CrossRef]

68. Buggele, W.A.; Johnson, K.E.; Horvath, C.M. Influenza A virus infection of human respiratory cells induces primary microRNA expression. J. Biol. Chem. 2012, 287, 31027-31040. [CrossRef]

69. Buggele, W.A.; Krause, K.E.; Horvath, C.M.; Pekosz, A. Small RNA profiling of influenza A virus-infected cells identifies miR-449b as a regulator of histone deacetylase 1 and interferon beta. PLoS ONE 2013, 8, e76560. [CrossRef]

70. Zhang, F.; Sun, X.; Zhu, Y.; Qin, W. Downregulation of miR-146a inhibits influenza A virus replication by enhancing the type I interferon response in vitro and in vivo. Biomed. Pharmacother. 2019, 111, 740-750. [CrossRef]

71. Rosenberger, C.M.; Podyminogin, R.L.; Diercks, A.H.; Treuting, P.M.; Peschon, J.J.; Rodriguez, D.; Gundapuneni, M.; Weiss, M.J.; Aderem, A.; Lopez, C.B. miR-144 attenuates the host response to influenza virus by targeting the TRAF6-IRF7 signaling axis. PLoS Pathog. 2017, 13, e1006305. [CrossRef]

72. Othumpangat, S.; Bryan, N.B.; Beezhold, D.H.; Noti, J.D. Upregulation of miRNA-4776 in Influenza Virus Infected Bronchial Epithelial Cells Is Associated with Downregulation of NFKBIB and Increased Viral Survival. Viruses 2017, 9, 94. [CrossRef]

73. Peng, X.; Gao, Q.S.; Zhou, L.; Chen, Z.H.; Lu, S.; Huang, H.J.; Zhan, C.Y.; Xiang, M. MicroRNAs in avian influenza virus H9N2-infected and non-infected chicken embryo fibroblasts. Genet. Mol. Res. 2015, 14, 9081-9091. [CrossRef]

74. Gao, S.; Li, J.; Song, L.; Wu, J.; Huang, W. Influenza A virus-induced downregulation of miR-26a contributes to reduced IFNalpha/beta production. Virol. Sin. 2017, 32, 261-270. [CrossRef]

75. Othumpangat, S.; Beezhold, D.H.; Umbright, C.M.; Noti, J.D. Influenza Virus-Induced Novel miRNAs Regulate the STAT Pathway. Viruses 2021, 13, 967. [CrossRef] [PubMed]

76. Othumpangat, S.; Noti, J.D.; Beezhold, D.H. Lung epithelial cells resist influenza A infection by inducing the expression of cytochrome c oxidase VIc which is modulated by miRNA 4276. Virology 2014, 468, 256-264. [CrossRef]

77. Dong, C.; Sun, X.; Guan, Z.; Zhang, M.; Duan, M. Modulation of influenza A virus replication by microRNA-9 through targeting MCPIP1. J. Med. Virol. 2017, 89, 41-48. [CrossRef] [PubMed]

78. Shen, X.; Sun, W.; Shi, Y.; Xing, Z.; Su, X.; Cantarini, L. Altered Viral Replication and Cell Responses by Inserting MicroRNA Recognition Element into PB1 in Pandemic Influenza A Virus (H1N1) 2009. Mediat. Inflamm. 2015, 2015, 976512-976575. [CrossRef] 
79. Huang, S.Y.; Huang, C.H.; Chen, C.J.; Chen, T.W.; Lin, C.Y.; Lin, Y.T.; Kuo, S.M.; Huang, C.G.; Lee, L.A.; Chen, Y.H.; et al. Novel Role for miR-1290 in Host Species Specificity of Influenza A Virus. Mol. Ther. Nucleic Acids 2019, 17, 10-23. [CrossRef]

80. Lin, J.; Chen, Y.T.; Xia, J.; Yang, Q. MiR674 inhibits the neuraminidase-stimulated immune response on dendritic cells via down-regulated Mbnl3. Oncotarget 2016, 7, 48978-48994. [CrossRef]

81. Zhang, S.; Li, J.; Li, J.; Yang, Y.; Kang, X.; Li, Y.; Wu, X.; Zhu, Q.; Zhou, Y.; Hu, Y. Up-regulation of microRNA-203 in influenza A virus infection inhibits viral replication by targeting DR1. Sci. Rep. 2018, 8, 6715-6797. [CrossRef]

82. Sharma, S.; Chatterjee, A.; Kumar, P.; Lal, S.; Kondabagil, K. Upregulation of miR-101 during Influenza A Virus Infection Abrogates Viral Life Cycle by Targeting mTOR Pathway. Viruses 2020, 12, 444. [CrossRef] [PubMed]

83. Cai, T.; Zhang, Q.; Wu, B.; Wang, J.; Li, N.; Zhang, T.; Wang, Z.; Luo, J.; Guo, X.; Ding, X.; et al. LncRNA-encoded microproteins: A new form of cargo in cell culture-derived and circulating extracellular vesicles. J. Extracell Vesicles 2021, 10, e12123. [CrossRef] [PubMed]

84. Zhang, X.; Wang, W.; Zhu, W.; Dong, J.; Cheng, Y.; Yin, Z.; Shen, F. Mechanisms and Functions of Long Non-Coding RNAs at Multiple Regulatory Levels. Int. J. Mol. Sci. 2019, 20, 5573. [CrossRef] [PubMed]

85. Wang, J.; Wang, Y.; Zhou, R.; Zhao, J.; Zhang, Y.; Yi, D.; Li, Q.; Zhou, J.; Guo, F.; Liang, C.; et al. Host Long Noncoding RNA IncRNA-PAAN Regulates the Replication of Influenza A Virus. Viruses 2018, 10, 330. [CrossRef] [PubMed]

86. Wang, J.; Zhang, Y.; Li, Q.; Zhao, J.; Yi, D.; Ding, J.; Zhao, F.; Hu, S.; Zhou, J.; Deng, T.; et al. Influenza Virus Exploits an Interferon-Independent lncRNA to Preserve Viral RNA Synthesis through Stabilizing Viral RNA Polymerase PB1. Cell Rep. 2019, 27, 3295-3304. [CrossRef]

87. Zhang, L.; Zheng, X.; Li, J.; Wang, G.; Hu, Z.; Chen, Y.; Wang, X.; Gu, M.; Gao, R.; Hu, S.; et al. Long noncoding RNA\#45 exerts broad inhibitory effect on influenza a virus replication via its stem ring arms. Virulence 2021, 12, 2443-2460. [CrossRef]

88. Zong, Z.; Zhang, Z.; Wu, L.; Zhang, L.; Zhou, F. The Functional Deubiquitinating Enzymes in Control of Innate Antiviral Immunity. Adv. Sci. 2021, 8, 2002484. [CrossRef]

89. Maarouf, M.; Chen, B.; Chen, Y.; Wang, X.; Rai, K.R.; Zhao, Z.; Liu, S.; Li, Y.; Xiao, M.; Chen, J.L. Identification of lncRNA-155 encoded by MIR155HG as a novel regulator of innate immunity against influenza A virus infection. Cell. Microbiol. 2019, 21, e13036. [CrossRef]

90. Pan, Q.; Zhao, Z.; Liao, Y.; Chiu, S.; Wang, S.; Chen, B.; Chen, N.; Chen, Y.; Chen, J. Identification of an Interferon-Stimulated Long Noncoding RNA (LncRNA ISR) Involved in Regulation of Influenza A Virus Replication. Int. J. Mol. Sci. 2019, $20,5118$. [CrossRef] [PubMed]

91. Lin, H.; Jiang, M.; Liu, L.; Yang, Z.; Ma, Z.; Liu, S.; Ma, Y.; Zhang, L.; Cao, X. The long noncoding RNA Lnczc3h7a promotes a TRIM25-mediated RIG-I antiviral innate immune response. Nat. Immunol. 2019, 20, 812-823. [CrossRef]

92. Lai, C.; Liu, L.; Liu, Q.; Wang, K.; Cheng, S.; Zhao, L.; Xia, M.; Wang, C.; Duan, Y.; Zhang, L.; et al. Long noncoding RNA AVAN promotes antiviral innate immunity by interacting with TRIM25 and enhancing the transcription of FOXO3a. Cell Death Differ. 2021, 28, 2900-2915. [CrossRef]

93. Zhao, L.; Xia, M.; Wang, K.; Lai, C.; Fan, H.; Gu, H.; Yang, P.; Wang, X. A Long Non-coding RNA IVRPIE Promotes Host Antiviral Immune Responses Through Regulating Interferon $\beta 1$ and ISG Expression. Front. Microbiol. 2020, 11, 260. [CrossRef] [PubMed]

94. Chen, Y.; Hu, J.; Liu, S.; Chen, B.; Xiao, M.; Li, Y.; Liao, Y.; Rai, K.R.; Zhao, Z.; Ouyang, J.; et al. RDUR, a lncRNA, Promotes Innate Antiviral Responses and Provides Feedback Control of NF-kB Activation. Front. Immunol. 2021, 12, 672165. [CrossRef] [PubMed]

95. Barriocanal, M.; Prior, C.; Suarez, B.; Unfried, J.P.; Razquin, N.; Hervás-Stubbs, S.; Sangro, B.; Segura, V.; Fortes, P. Long Noncoding RNA EGOT Responds to Stress Signals to Regulate Cell Inflammation and Growth. J. Immunol. 2021, 206, 1932-1942. [CrossRef]

96. Carnero, E.; Barriocanal, M.; Prior, C.; Pablo Unfried, J.; Segura, V.; Guruceaga, E.; Enguita, M.; Smerdou, C.; Gastaminza, P.; Fortes, P. Long noncoding RNA EGOT negatively affects the antiviral response and favors HCV replication. EMBO Rep. 2016, 17, 1013-1028. [CrossRef]

97. Liu, S.; Liu, J.; Yang, X.; Jiang, M.; Wang, Q.; Zhang, L.; Ma, Y.; Shen, Z.; Tian, Z.; Cao, X. Cis-acting lnc-Cxcl2 restrains neutrophilmediated lung inflammation by inhibiting epithelial cell CXCL2 expression in virus infection. Proc. Natl. Acad. Sci. USA 2021, 118. [CrossRef]

98. Ghafouri-Fard, S.; Abak, A.; Shoorei, H.; Talebi, S.F.; Mohaqiq, M.; Sarabi, P.; Taheri, M.; Mokhtari, M. Interaction between non-coding RNAs and Toll-like receptors. Biomed. Pharmacother. 2021, 140, 111784. [CrossRef] [PubMed]

99. More, S.; Zhu, Z.; Lin, K.; Huang, C.; Pushparaj, S.; Liang, Y.; Sathiaseelan, R.; Yang, X.; Liu, L. Long non-coding RNA PSMB8-AS1 regulates influenza virus replication. RNA Biol. 2019, 16, 340-353. [CrossRef]

100. Li, X.; Guo, G.; Lu, M.; Chai, W.; Li, Y.; Tong, X.; Li, J.; Jia, X.; Liu, W.; Qi, D.; et al. Long Noncoding RNA Lnc-MxA Inhibits Beta Interferon Transcription by Forming RNA-DNA Triplexes at Its Promoter. J. Virol. 2019, 93, e00786-19. [CrossRef] [PubMed]

101. Almatrrouk, S.; Saba, I.; Abozaid, S.; Al-Qahtani, A.A.; Al-Ahdal, M.N. Virus sensing receptors in cellular infectivity of influenza A virus. J. Infect. Dev. Countr. 2021, 15, 1-8. [CrossRef] [PubMed]

102. Li, J.; Li, M.; Wang, X.; Sun, M.; Ma, C.; Liang, W.; Gao, X.; Wei, L. Long Noncoding RNA NRAV Promotes Respiratory Syncytial Virus Replication by Targeting the MicroRNA miR-509-3p/Rab5c Axis to Regulate Vesicle Transportation. J. Virol. 2020, 94, e00113-20. [CrossRef] [PubMed]

103. Winterling, C.; Koch, M.; Koeppel, M.; Garcia-Alcalde, F.; Karlas, A.; Meyer, T.F. Evidence for a crucial role of a host non-coding RNA in influenza A virus replication. RNA Biol. 2014, 11, 66-75. [CrossRef] [PubMed] 
104. Jiang, M.; Zhang, S.; Yang, Z.; Lin, H.; Zhu, J.; Liu, L.; Wang, W.; Liu, S.; Liu, W.; Ma, Y.; et al. Self-Recognition of an Inducible Host lncRNA by RIG-I Feedback Restricts Innate Immune Response. Cell 2018, 173, 906-919. [CrossRef]

105. Runtsch, M.C.; O'Neill, L.A. GOTcha: LncRNA-ACOD1 targets metabolism during viral infection. Cell Res. 2018, 28, 137-138. [CrossRef] [PubMed]

106. Wang, P.; Xu, J.; Wang, Y.; Cao, X. An interferon-independent lncRNA promotes viral replication by modulating cellular metabolism. Science (Am. Assoc. Adv. Sci.) 2017, 358, 1051-1055. [CrossRef]

107. Amort, M.; Nachbauer, B.; Tuzlak, S.; Kieser, A.; Schepers, A.; Villunger, A.; Polacek, N. Expression of the vault RNA protects cells from undergoing apoptosis. Nat. Commun. 2015, 6, 7030. [CrossRef] [PubMed]

108. Li, F.; Chen, Y.; Zhang, Z.; Ouyang, J.; Wang, Y.; Yan, R.; Huang, S.; Gao, G.F.; Guo, G.; Chen, J. Robust expression of vault RNAs induced by influenza A virus plays a critical role in suppression of PKR-mediated innate immunity. Nucleic Acids Res. 2015, 43, 10321-10337. [CrossRef]

109. Ge, J.; Wang, J.; Xiong, F.; Jiang, X.; Zhu, K.; Wang, Y.; Mo, Y.; Gong, Z.; Zhang, S.; He, Y.; et al. Epstein-Barr virus-encoded circular RNA circBART2.2 promotes immune escape of nasopharyngeal carcinoma by regulating PD-L1. Cancer Res. 2021, 81, 5074-5088. [CrossRef]

110. Hu, Y.; Xu, Y.; Deng, X.; Wang, R.; Li, R.; You, L.; Song, J.; Zhang, Y. Comprehensive analysis of the circRNA expression profile and circRNA-miRNA-mRNA network in the pathogenesis of EV-A71 infection. Virus Res. 2021, 303, 198502. [CrossRef]

111. Zhao, W.; Su, J.; Wang, N.; Zhao, N.; Su, S. Expression Profiling and Bioinformatics Analysis of CircRNA in Mice Brain Infected with Rabies Virus. Int. J. Mol. Sci. 2021, 22, 6537. [CrossRef]

112. Choudhary, A.; Madbhagat, P.; Sreepadmanabh, M.; Bhardwaj, V.; Chande, A. Circular RNA as an Additional Player in the Conflicts between the Host and the Virus. Front. Immunol. 2021, 12, 602006. [CrossRef]

113. Qu, Z.; Meng, F.; Shi, J.; Deng, G.; Zeng, X.; Ge, J.; Li, Y.; Liu, L.; Chen, P.; Jiang, Y.; et al. A Novel Intronic Circular RNA Antagonizes Influenza Virus by Absorbing a microRNA That Degrades CREBBP and Accelerating IFN- $\beta$ Production. MBio 2021, e01017-21. [CrossRef]

114. Yu, T.; Ding, Y.; Zhang, Y.; Liu, Y.; Li, Y.; Lei, J.; Zhou, J.; Song, S.; Hu, B. Circular RNA GATAD2A promotes H1N1 replication through inhibiting autophagy. Vet. Microbiol. 2019, 231, 238-245. [CrossRef] [PubMed]

115. Ouyang, J.; Zhu, X.; Chen, Y.; Wei, H.; Chen, Q.; Chi, X.; Qi, B.; Zhang, L.; Zhao, Y.; Gao, G.F.; et al. NRAV, a Long Noncoding RNA, Modulates Antiviral Responses through Suppression of Interferon-Stimulated Gene Transcription. Cell Host Microbe 2014, 16, 616-626. [CrossRef] [PubMed]

116. Imamura, K.; Imamachi, N.; Akizuki, G.; Kumakura, M.; Kawaguchi, A.; Nagata, K.; Kato, A.; Kawaguchi, Y.; Sato, H.; Yoneda, M.; et al. Long noncoding RNA NEAT1-dependent SFPQ relocation from promoter region to paraspeckle mediates IL8 expression upon immune stimuli. Mol. Cell 2014, 53, 393-406. [CrossRef]

117. Chai, W.; Li, J.; Shangguan, Q.; Liu, Q.; Li, X.; Qi, D.; Tong, X.; Liu, W.; Ye, X.; Gallagher, T. Lnc-ISG20 Inhibits Influenza A Virus Replication by Enhancing ISG20 Expression. J. Virol. 2018, 92, e00539-18. [CrossRef]

118. Xiao, M.; Chen, Y.; Wang, S.; Liu, S.; Rai, K.R.; Chen, B.; Li, F.; Li, Y.; Maarouf, M.; Chen, J. LncRNA IFITM4P regulates host antiviral responses by acting as a ceRNA. J. Virol. 2021, I27721. [CrossRef]

119. Wang, Q.; Zhang, D.; Feng, W.; Guo, Y.; Sun, X.; Zhang, M.; Guan, Z.; Duan, M. Long noncoding RNA TSPOAP1 antisense RNA 1 negatively modulates type I IFN signaling to facilitate influenza A virus replication. J. Med. Virol. 2019, 94, 557-566. [CrossRef]

120. Tu, Y.H.; Guo, Y.; Ji, S.; Shen, J.L.; Fei, G.H. The Influenza A Virus H3N2 Triggers the Hypersusceptibility of Airway Inflammatory Response via Activating the lncRNA TUG1/miR-145-5p/NF-kappaB Pathway in COPD. Front. Pharmacol. 2021, 12, 604590. [CrossRef]

121. Shi, N.; Zhang, S.; Guo, Y.; Yu, X.; Zhao, W.; Zhang, M.; Guan, Z.; Duan, M. CircRNA_0050463 promotes influenza A virus replication by sponging miR-33b-5p to regulate EEF1A1. Vet. Microbiol. 2021, 254, 108995. [CrossRef] [PubMed]

122. Khongnomnan, K.; Saengchoowong, S.; Mayuramart, O.; Nimsamer, P.; Pisitkun, T.; Poovorawan, Y.; Payungporn, S. HsamiR-30e-3p inhibits influenza B virus replication by targeting viral NA and NP genes. Exp. Biol. Med. 2020, 245, $1664-1671$. [CrossRef]

123. Liu, H.; Yang, X.; Zhang, Z.; Zou, W.; Wang, H. miR-146a-5p promotes replication of infectious bronchitis virus by targeting IRAK2 and TNFRSF18. Microb. Pathog. 2018, 120, 32-36. [CrossRef]

124. Li, H.; Li, J.; Zhai, Y.; Zhang, L.; Cui, P.; Feng, L.; Fu, X.; Tian, Y.; Wang, H.; Yang, X.; et al. Gga-miR-30d regulates infectious bronchitis virus infection by targeting USP47 in HD11 cells. Microb. Pathog. 2020, 141, 103998. [CrossRef]

125. Li, H.; Cui, P.; Fu, X.; Zhang, L.; Yan, W.; Zhai, Y.; Lei, C.; Wang, H.; Yang, X. Identification and analysis of long non-coding RNAs and mRNAs in chicken macrophages infected with avian infectious bronchitis coronavirus. BMC Genom. 2021, 22, 67. [CrossRef]

126. Carrique, L.; Fan, H.; Walker, A.P.; Keown, J.R.; Sharps, J.; Staller, E.; Barclay, W.S.; Fodor, E.; Grimes, J.M. Host ANP32A mediates the assembly of the influenza virus replicase. Nature 2020, 587, 638-643. [CrossRef]

127. Sato, K.; Hayashi, H.; Shimotai, Y.; Yamaya, M.; Hongo, S.; Kawakami, K.; Matsuzaki, Y.; Nishimura, H. TMPRSS2 activates hemagglutinin-esterase glycoprotein of influenza C virus. J. Virol. 2021, 95, I129621. [CrossRef]

128. Saengchoowong, S.; Khongnomnan, K.; Poomipak, W.; Praianantathavorn, K.; Poovorawan, Y.; Zhang, Q.; Payungporn, S. High-Throughput MicroRNA Profiles of Permissive Madin-Darby Canine Kidney Cell Line Infected with Influenza B Viruses. Viruses 2019, 11, 986. [CrossRef] [PubMed] 
129. Liang, H.; Zhang, X.; Liu, B.; Jia, G.; Li, W. Circular RNA circ-ABCB10 promotes breast cancer proliferation and progression through sponging miR-1271. Am. J. Cancer Res. 2017, 7, 1566-1576. [PubMed]

130. Qiu, F.; Chen, H.; Ying, H.; Yu, W.; Guo, M.; Zhou, W.; Yu, C. A Biological Insight into the Susceptibility to Influenza Infection in Junior Rats by Comprehensive Analysis of lncRNA Profiles. Biomed Res. Int. 2021, 2021, 8112783. [CrossRef]

131. Fukuyama, H.; Shinnakasu, R.; Kurosaki, T. Influenza vaccination strategies targeting the hemagglutinin stem region. Immunol. Rev. 2020, 296, 132-141. [CrossRef] [PubMed]

132. Deng, L.; Mohan, T.; Chang, T.Z.; Gonzalez, G.X.; Wang, Y.; Kwon, Y.M.; Kang, S.-M.; Compans, R.W.; Champion, J.A.; Wang, B.-Z. Influenza NP core and HA or M2e shell double-layered protein nanoparticles induce broad protection against divergent influenza a viruses. Nanomed. Nanotechnol. Biol. Med. 2021, 9, 102479. [CrossRef]

133. Chen, J.; Yuan, L.; Fan, Q.; Su, F.; Chen, Y.; Hu, S. Adjuvant effect of docetaxel on the immune responses to influenza A H1N1 vaccine in mice. BMC Immunol. 2012, 13, 36. [CrossRef] [PubMed]

134. Peng, S.; Wang, J.; Wei, S.; Li, C.; Zhou, K.; Hu, J.; Ye, X.; Yan, J.; Liu, W.; Gao, G.F.; et al. Endogenous Cellular MicroRNAs Mediate Antiviral Defense against Influenza A Virus. Mol. Ther. Nucleic Acids 2018, 10, 361-375. [CrossRef] [PubMed]

135. Gao, F.; Yang, T.; Liu, X.; Xiong, F.; Luo, J.; Yi, Y.; Fan, J.; Chen, Z.; Tan, W.-S. MiRNA Targeted NP Genome of Live Attenuated Influenza Vaccines Provide Cross-Protection against a Lethal Influenza Virus Infection. Vaccines 2020, 8, 65. [CrossRef] [PubMed] 